\author{
SCHOOL COMPETITION AND TEACHER LABOR MARKETS: \\ EVIDENCE FROM CHARTER SCHOOL ENTRY IN NORTH CAROLINA \\ C. Kirabo Jackson \\ Working Paper 17225 \\ http://www.nber.org/papers/w17225
}

\author{
NATIONAL BUREAU OF ECONOMIC RESEARCH \\ 1050 Massachusetts Avenue \\ Cambridge, MA 02138 \\ July 2011
}

I would like to thank Kara Bonneau for help in obtaining data from the North Carolina Education Research Data Center, and David Figlio, Mark Steinmeyer, and Diane Schanzenbach for valuable comments. I am particularly grateful to James Cowan for excellent research assistance. Funding for this research was provided by the Smith Richardson Foundation. All errors are my own. The views expressed herein are those of the author and do not necessarily reflect the views of the National Bureau of Economic Research.

NBER working papers are circulated for discussion and comment purposes. They have not been peerreviewed or been subject to the review by the NBER Board of Directors that accompanies official NBER publications.

(C) 2011 by C. Kirabo Jackson. All rights reserved. Short sections of text, not to exceed two paragraphs, may be quoted without explicit permission provided that full credit, including $\odot$ notice, is given to the source. 
School Competition and Teacher Labor Markets: Evidence from Charter School Entry in North Carolina

C. Kirabo Jackson

NBER Working Paper No. 17225

July 2011

JEL No. I2,I28,J00,J18

\begin{abstract}
$\underline{\text { ABSTRACT }}$
I analyze changes in teacher turnover, hiring, effectiveness, and salaries at traditional public schools after the opening of a nearby charter school. While I find small effects on turnover overall, difficult to staff schools (low-income, high-minority share) hired fewer new teachers and experienced small declines in teacher quality. I also find evidence of a demand side response where schools increased teacher compensation to better retain quality teachers. The results are robust across a variety of alternate specifications to account for non-random charter entry.

C. Kirabo Jackson

Northwestern University

School of Education and Social Policy

2040 Sheridan Road

Evanston, IL 60208

and NBER

kirabo-jackson@northwestern.edu
\end{abstract}




\title{
School Competition and Teacher Labor Markets: Evidence from Charter School Entry in North Carolina
}

\author{
C. Kirabo Jackson \\ Northwestern University \& IPR \& NBER
}

I analyze changes in teacher turnover, hiring, effectiveness, and salaries at traditional public schools after the opening of a nearby charter school. While I find small effects on turnover overall, difficult to staff schools (lowincome, high-minority share) hired fewer new teachers and experienced small declines in teacher quality. I also find evidence of a demand side response where schools increased teacher compensation to better retain quality teachers. The results are robust across a variety of alternate specifications to account for non-random charter entry.

Increasing school competition is seen as one way to improve students' outcomes. Many school reforms such as school vouchers, school choice, and charter schools, are predicated, in part, on the notion that increased competitive pressures cause schools to use their scarce resources more efficiently (Friedman 1955, 1997). However, opponents of school competition argue that such policies deprive existing schools of much needed resources, and may lead to cream skimming of good students, and good teachers from already underperforming schools. ${ }^{1}$ Adding fuel to this debate, the empirical evidence on the effect of increased competition on students at pre-existing Traditional Public Schools (TPSs) is decidedly mixed. ${ }^{2}$

One of the hypothesized mechanisms through which increased competition could affect student outcomes is by changing the distribution of teachers across schools. Recent evidence suggests that there are large differences in teacher quality, and these differences translate into substantial differences in student achievement (Hanushek et. al. 2005, Rockoff 2004, Aaronson, Barrow and Sander 2007). Hence, given mixed evidence on how school competition affects student achievement in TPSs, and the push to increase competition in public education by

\footnotetext{
${ }^{1}$ There is an important but subtle distinction between school competition in the Tiebout sense between multiple public education providers who are subject to the same rules and personnel practices, and the increased competitive pressure caused by recent policies such as charter schools, alternative schools, and vouchers that introduce different kinds of schools to compete with traditional public school that may have different personnel practices and be subject to different rules and restrictions. While the two are related, this paper speaks to the later.

${ }^{2}$ Hoxby (2000) and Rothstein (2007) analyze the competition provided by multiple public school districts in the same metropolitan area and come to different conclusions; Dee (1998) finds positive effects of competition provided by Catholic schools; Looking at the effect of charter school entry on traditional public school students studies find negative effects (Imberman 2011), no effect (Bettinger 2005; Bifulco and Ladd 2006), and small positive effects (Sass 2006). As such, how increased school competition affects student outcomes at traditional schools is still an unresolved question.
} 
expanding charter schools ${ }^{3}$, it is important to understand the role of teachers.

The effect that increased school competition would have on teachers at pre-existing TPSs is theoretically ambiguous. On the supply side, TPSs that face increased competition may experience difficulties attracting and retaining good teachers. However, on the demand side, because funding is tied to student enrolment, TPSs that face competition for students have an increased incentive to hire and keep teachers who help attract students (Hoxby 2002). Because supply and demand factors move in opposite directions, the net effect on teacher quality and teacher turnover in TPSs is ambiguous, and small effects on turnover or teacher quality do not imply a lack of competitive pressure. That is, because schools may respond to the threat of teachers leaving by paying higher salaries, competitive pressure could be reflected in higher salaries rather than teacher turnover or quality. Also, because schools constantly have to hire new teachers due to high teacher turnover, competitive supply-side pressure may be reflected in reduced hiring rather than increased turnover. As such, one should look at the effects on various measures of labor quantity (turnover, new hires, quality), in addition to teacher salaries.

The existing research on competition and teachers relies on comparisons across geographic areas and finds that increased competitive pressure is associated with schools valuing teacher effort, the quality of teachers' college education, and teachers' math and science skills (Hoxby 2002), higher teacher quality (Hanushek and Rivkin 2003), and higher public school teacher salaries (Vedder and Hall 2000). Given the limitations of cross-sectional analyses, these studies may not provide direct evidence on how competition affects the quality of, or salaries paid to, teachers at incumbent TPSs. Moreover, these studies do not simultaneously look at quality, new hires, turnover, and salaries, which may be necessary for a complete description of the impact of school competition on teachers in TPSs. Another literature compares charter teachers to TPS teachers to assess whether competing charter schools attract good teachers from TPSs (Podgursky and Ballou 2001, Burian-Fitzgerald and Harris 2004, Baker and Dickerson 2006, Caruthers 2009). While informative, these studies do not show how school competition affects teachers in TPSs because teachers who transfer to charter schools from TPSs may have

\footnotetext{
${ }^{3}$ For example, President Obama stated that "many of the innovations in education today are happening in charter schools", and suggested that charter schools should be expanded [source: speech given to the Council of Chief State School officers, March 10, 2009, Washington D.C.]. Also, secretary of Education Arne Duncan is stated that "States that do not have public charter laws or put artificial caps on the growth of charter schools will jeopardize their applications under the Race to the Top Fund." [source: U.S. Dept of Education press release June 8, 2009, States Open to Charters Start Fast in 'Race to Top']
} 
left these schools absent charter competition. To understand how school competition affects the market for TPS teachers, it would be instructive to observe how teacher markets respond to charter school entry in the surrounding area.

I provide fresh evidence on how school competition affects teachers in TPSs by looking at a variety of outcomes to more completely characterize the teacher labor market and use the entry of a nearby charter school as an arguably exogenous increase in school competition. Specifically, I test whether charter school entry affects (a) the likelihood that a TPS teacher leaves her school, (b) the quality of teachers in incumbent schools, (c) the number of newly hired teachers at incumbent schools, and (d) the wages paid to traditional public school teachers.

I use two measures of teacher quality; the first is an index of teacher quality or predicted value-added based on observable teacher characteristics that can be created for all teachers; the second is estimated value-added that is available only for the sub-sample of 3rd through 5th grade teachers who had been in North Carolina public schools for a long period of time.

To identify the effect of charter competition, I employ a Difference in Differences strategy - comparing the change in outcomes within schools after charter entry to the change in outcomes within schools that face no changes in charter entry over the same time period. This strategy relies on variation in timing of charter entry. While this within-school approach removes much bias, because timing of charter entry is non-random, I show that (1) the main findings are robust to including school-specific linear trends, (2) the findings are robust to using interrupted panel data techniques, and (3) I present visual evidence that changes in outcomes occur after charter entry. I am reasonably confident the estimates can be interpreted causally.

On average, teachers who leave TPSs for charter schools have worse observable characteristics and value-added than those who remain. While more teachers leave for charter schools after the opening of a nearby charter (a mechanical effect), charter entry is not associated with an increase in teachers leaving TPSs overall - implying that those teachers who left for charter schools would have left the TPSs absent charter entry. While I find no effect on teacher quality, nearby charter entry is associated with increases in teacher compensation and reductions in the number of newly teacher hires - suggestive of (a) a demand response of incumbent schools to retain teachers, and (b) a supply effect making it harder to attract new teachers.

To further test that the effects are driven by increased competitive pressure, I look to see if the marginal effects are larger at "difficult to staff" schools (schools with high minority and 
low-income student shares) where teachers would be most responsive to alternate teaching opportunities. I find that the increases in teacher compensation and the reductions in new teacher hiring are much more pronounced in these difficult to staff schools, and I find evidence of declines in teacher quality - indicating that charter entry could lead to unfilled teacher vacancies, lower quality instruction, and less expenditure on non-teacher inputs (because increased teacher pay must come at the expense of other spending) at "difficult to staff" schools.

This is one of the first papers to investigate how arguably exogenous variation in school competition affects a variety of teacher labor market outcomes. The media often cites skimming away quality teachers from TPSs as one way charters either produce gains for their own students or hurt students in TPSs. ${ }^{4}$ This research advances this argument by providing evidence on how charter schools affect the labor market for teachers within the existing TPS system, and shows that spillovers from the teacher market could affect other resources.

The remainder of the paper is as follows. Section I presents a theoretical framework. Section II describes charters in North Carolina and details the characteristics of teachers who move from TPSs to charter schools. Section III describes the identification strategy. Section IV presents the results, and section $\mathrm{V}$ concludes.

\section{Theoretical Framework}

Charter school competition may affect teacher labor markets both through the decisions of teachers (supply-side) and through the decisions of school administrators (demand-side). I discuss these mechanisms below.

Supply Side Effects Only: On the supply side, increased school competition could affect teacher characteristics in traditional public schools through several channels. First, charter entry may cause increased attrition from nearby incumbent schools, forcing public schools to rely more heavily on new, inexperienced teachers. Second, if charter schools demand different kinds of teachers than TPSs, charter schools' preferences for teachers may alter the composition of teachers leaving incumbent schools. ${ }^{5}$ Finally, because a greater number of schools in a given

\footnotetext{
${ }^{4}$ Media stories often suggest charter schools attract teachers by offering good students and facilities [see, e.g., Fallis and Keating (2008), Keating and Labbe-DeBose (2008)]. One charter school recently founded in New York City, for instance, is founded on the premise of attracting quality teachers with high salaries (Gootman 2008).

${ }^{5}$ Podgursky and Ballou (2001) present survey evidence that charter schools are more willing to hire teachers with less experience and fewer official credentials. The improved job prospects for these teachers may cause more of them to leave traditional public schools.
} 
geographic area makes it harder to attract talented teachers to any individual school, charter competition may reduce the quantity and quality of new teachers applying for positions at TPSs.

The notion that teachers at schools close to newly entering charter schools would be affected by charter entry requires that teacher labor markets are localized. Martin (2000) observes that workers generally frequently exhibit a strong attachment to place resulting in the “spatial fixity” of local labor. Also, Gregory and Borland (1999) and Murnane and Steele (2007) argue that markets for teachers reflect restricted geographic scope. Consistent with this about sixty percent of new teachers in California begin teaching in the same county where they were employed before teaching (Barbour, Reed and Rubin 2006). Also first year teachers in New York state are twice as likely to teach within five miles of her hometown as 20 miles away. Consistent with this, in 1996 two-thirds of all teacher switching in NC occurred within the same district.

The localized nature of teacher labor supply means that the wage elasticity of labor supply for a school is positive so that each school faces an upward sloping teacher labor supply curve. The degree to which charter entry will affect labor supply for a particular TPS depends on (a) the number of teachers hired at the charter school and (b) the proximity of the opening school to the public school. Because one third of charter teachers came from TPSs (Caruthers 2010) and teachers have strong preferences for proximity, while charter entry may have small effects in the aggregate, it could have large effects on the labor supply to nearby TPSs.

Figure 1 illustrates this graphically. The left side shows the number of teachers hired at a local charter school, and the right shows the associated change in teacher supply for nearby TPSs. I assume that teachers only work at schools located in their "teacher supply area” so that labor supply within a teacher supply area is depicted by the curve $\mathrm{S}_{0}$. When a charter enters it hires $\mathrm{L}_{\text {charter }}$ teachers. Because of the limited geography of the "teacher supply area” some of these teachers would have worked at the nearby TPSs but now no longer do so. This reduces labor supply for the nearby public schools as depicted by a shift in labor supply from $S_{0}$ to $S_{1}$.

How this entry will affect employment depends on the ability of individual schools to adjust wages. In a rigid wage regime, wages are set to $\mathrm{Wu}$ irrespective of the number of teachers required. The number of teachers hired will be where $\mathrm{Wu}$ intersects with the new labor supply so that TPS employment falls from $L_{0}$ to $L_{1}$ (fewer teachers are now willing to work at the traditional public schools at the pre-entry wage). There would be no change in teacher compensation, increases in teacher turnover, and reductions in the number of new teachers hired. 
If schools have some flexibility to pay some teacher higher wages then the wage regime would be similar to having a downward sloping labor demand curve (this may not necessarily reflect depict the marginal revenue product of labor). Schools in NC do have some ability to affect teacher compensation. While all certified NC educators working in Local Education Agencies (LEA) are required to be paid from the legislated salary schedule that sets a minimum pay based on the educators years of experience and education level, a supplement to these monthly amounts can be approved to account for variances such as geographic location, market conditions or school demographics. Also, school principals can (and do) create compensation differences across teachers without altering their base pay by creating mentor teacher positions, training positions, administrative positions, coaching positions, extra teaching time, and summer teaching that carry additional salary. As such, while somewhat limited, principals do have the ability to affect teacher compensation so that the "labor demand" curve is not horizontal.

As depicted in Figure 1, with wage flexibility (and a downward sloping labor demand

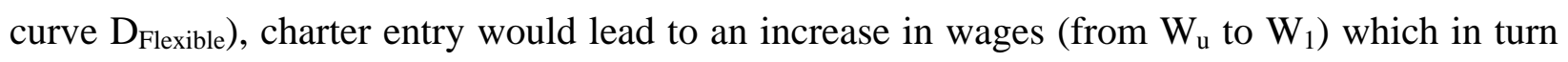
would result in a smaller reduction in teachers employed from $L_{0}$ to $L_{2}$. With flexible wages there is an increase in teacher wages, and increases in teacher turnover and reductions in new teacher hiring that are smaller than the changes one would observe under rigid wages.

Both Supply Side and Demand -Side Effects: On the demand side, because schools operate like local monopolies, school competition could affect the incentives of public school administrators. Specifically, because quality teachers may attract students and funding is on a per-student basis, when students "vote with their feet" schools may work harder to attract and retain teachers that parents prefer (Friedman 1955, 1997; Hoxby 2002). If parents know which teachers are effective, public schools facing charter competition should be more (less) willing to hire and retain teachers with characteristics that are (not) known to be associated with improved student outcomes. Schools would do this by offering higher salaries to, or improving the non-pecuniary job characteristics of desirable teachers. Similarly, if parents dislike teacher turnover in general, the increased ability of students to flee the TPSs after a nearby charter opens would increase the marginal benefit of retaining all teachers (avoiding increased turnover) so that schools may wish to increase pay for teachers of all quality.

As depicted in Figure 2, where schools have a demand response and have wage flexibility, charter entry will lead to a shift in the labor demand curve from $D_{0, \text { Flexible }}$ to $D_{1, \text { Flexible }}$. 
Now, even though supply side pressure would lead to a reduction in supply or quality teachers to TPSs and demand side factors should lead to an increase in demand for teachers, both supply and demand shifts cause upward pressure on teacher wages in TPSs. These offsetting effects may cause competitive pressure to manifest itself into no change (and possibly even an increase) in teacher quality or quantity, but would lead to an increase in teacher salaries from $\mathrm{W}_{0}$ to $\mathrm{W}_{2}$. With flexible wages and an off-setting demand side response, increases in wages will be larger than that with no demand side response. Also, changes in teacher turnover and new hires would be smaller (and possibly opposite in sign) than those with no demand side response. While I cannot disaggregate the overall changes into supply- and demand-side effects, I can test for the presence of competitive pressure by seeing if there is an effect on teacher salaries, and can assess whether demand-side or supply-side pressures dominate overall.

\section{Charter Schools and Teachers in North Carolina and the Data.}

The North Carolina legislature ratified a law allowing charter schools in 1996, and the first charters opened a year later (N. Car. Gen. St., 115C-238.29). As in many states, charter schools in North Carolina are managed by an independent board under a chartering contract with a LEA or university; however, they receive public funding based on the number of enrolled students. While some charters can be obtained by a local LEA or the state, in North Carolina none of the charters are sponsored by the state and are all managed by independent boards. ${ }^{6}$ The public funding received by charter schools would otherwise be earmarked for the school district in which the student resides. Charter schools are given greater flexibility in management than traditional public schools. They are subject to state testing and other requirements, but exempt from many state laws regulating personnel and operations. Notably, charter schools in NC are partially exempt from regulations requiring state certification of public school teachers. ${ }^{7}$

Table 1 gives information on charter entry and teacher movement to charter schools during the time period covered in this study. The law capped the total number of charter schools

\footnotetext{
${ }^{6}$ This is based on conversations with the officials at the office of charter schools at the state board of education on June 2, 2011. During these conversations I was told that the relationship between charter schools and the surrounding TPS are generally contentious - suggesting that North Carolina is a good context to study charter competition.

7 The law authorizing charter schools stipulates that $75 \%$ of elementary and middle school teachers and $50 \%$ of junior and senior high school teachers be state licensed. The remainder of the faculty may be appointed as the school deems fit, provided they meet federal requirements. The North Carolina law is consistent with management practices of charter schools elsewhere. Podgursky and Ballou (2001) found that fewer than 20\% of charter schools employed faculties with more than $50 \%$ unlicensed teachers.
} 
at 100, and by 2005, 99 charters were operating statewide. The data in this study come from North Carolina Department of Public Instruction administrative records maintained by the North Carolina Education Research Data Center. The records contain detailed professional and demographic information on all teachers active in North Carolina public schools from 1995 through 2006. In addition, the data contains test scores for all public school students state-wide.

The turnover statistics in Table 1 come from comparing the school assignments of teachers in consecutive years. Teachers who change school assignments or leave the data at the end of the school year are coded as exiting their school. ${ }^{8}$ While many teachers leave their TPS every year (about 17 percent in 1997) a small fraction of them leave for charter schools (about 0.1 percent). Since the effect of charter school entry is likely to be localized to areas close to charter schools I compute the fraction of TPS teachers at schools within 2 miles, between 2 and 10 miles, and between 10 and 20 miles of a charter school, who exit for charters. In 1997, the year with the greatest charter entry, 0.8 percent of teachers at schools within 2 miles of a charter school exited to a charter school. This percentage drops sharply beyond 2 miles such that only 0.2 percent of teachers at schools between 2 and 10 miles of a charter school exited to a charter school (not much more than the average for all schools in North Carolina of 0.1 percent). This is consistent with localized teacher labor markets effect. As argued above, the relatively low proportion of teachers who move from TPSs to charters does not mean that charter schools have no effect on the labor market for TPS teachers because it could reflect offsetting demand and supply effects. To assess the nature of competitive pressure on the teacher labor market, one must look at turnover, the characteristics of new hires and teacher salaries as I do in section IV.

Table 2 documents the characteristics of public schools, charter schools, and the public schools located near charter schools using data on neighborhood characteristics from the 2000 Census and enrollment information from the Common Core of Data (years 1995 through 2006). Charter schools in North Carolina are more likely than TPSs to be located in cities; however, more than $30 \%$ of charters are located in small towns or rural areas. About 53 percent of charter schools are in a large or medium sized city compared to $45 \%$ for TPSs in NC as a whole. Consistent with charter schools being located in more urban settings, the average proportion of white and black residents in charter neighborhoods are 66 percent and 27 percent, respectively,

\footnotetext{
${ }^{8}$ Many teachers take one- or two-year leaves of absence during the sample period. These teachers are not coded as exiting provided they return to their original school.
} 
compared to 71 percent and 23 percent, respectively, for the state as a whole.

Schools close to charter schools differ from those that are farther away and do not face charter competition. Schools within 2 miles of a charter school are more likely to be in an urban neighborhood (74 percent) than schools between 2 and 10 miles from a charter (60 percent) and those between 10 and 20 miles from a charter (24 percent). These differences highlight the importance of looking at changes within schools as opposed to comparing schools that are close to charter schools to those that are not. There are also important differences by the ethnic and socioeconomic composition of the neighborhoods. Schools within 2 miles of a charter school are in areas with more black residents (30.6 percent) than schools between 2 and 10 miles from a charter (22.4 percent) and those between 10 and 20 miles from a charter (17.5 percent). Also, schools within 2 miles of a charter school are in areas with median incomes of $\$ 38,820$, while schools between 2 and 10 miles from a charter have median incomes of $\$ 41,787$ and those between 10 and 20 miles from a charter have median incomes of \$39,012.

Because teachers care about workplace conditions when deciding where to work, it is helpful to describe how charter schools differ from TPSs. While charter schools may be located in areas where there are other schools, because charter enrollment is voluntary, charter schools often do not enroll students typical of those at surrounding schools. For example, the average charter school enrolls 50.9\% white students, compared to 59.7\% white in all North Carolina public schools and $46.1 \%$ in public schools within a 2-mile radius of a charter school. Charter schools are also less likely to enroll low-income students, as measured by free-lunch eligibility, than other public schools. The average charter school has $14.1 \%$ free-lunch eligibility, compared to $36.6 \%$ for all North Carolina public schools and $42.3 \%$ for public schools within 2 miles of a charter. It is worth noting that while charter schools have smaller enrollments (207 students at charters compared to 610 for the state and 594 for schools within 2 miles of a charter) the student teacher ratios at charter schools are similar to those schools within 2 miles, but lower than schools more than 2 miles away. The summary statistics suggest that charter schools may provide an easier working environment than those at public schools near to charters. Consistent with this notion, in a state-wide survey from 2002, charter teachers in NC were more likely to strongly agree that "Teachers are centrally involved in decision making", "Teachers are recognized as experts", "There is an atmosphere of mutual respect at school", "leadership tries to address concerns about time", and that "Teachers have reasonable student loads". These survey 
results (in appendix Table 1) and summary statistics suggest that charter schools may be an attractive alternative for teachers teaching in, or considering a teaching job, at a TPS.

\section{II.1 The Teacher Data}

Because this study is focused on teachers in TPSs, I only require data on TPS teachers. However, it may be informative to discuss the characteristics of charter school teachers. While I do not have data on the entire universe of charter school teachers, Burian-Fitzgerald and Harris (2004) analyze the differences between charter school teachers and public school teachers by state using the NCES Schools and Staffing Survey for 1999-2000. They found that charter school teachers in NC were less experienced and less likely to hold a teaching certificate, but more likely to have graduated from a selective college. Given that over 40 percent of charter teachers came from TPSs, one might infer that these are the types of teachers that leave TPSs for charters. I formally assess this in Section II.3.

Table 3 provides summary statistics of public school teachers and those moving from TPSs to charter schools. The data include several characteristics including years of experience, state teaching licensure, possession of an advanced degree, National Board Certification, the $75^{\text {th }}$ percentile SAT math score of the teacher's undergraduate institution, and teacher's Praxis scores. ${ }^{9}$ I also look at measures of unobserved teacher quality. I discuss these below.

\section{II.2 Measures of Teacher Quality}

Predicted Value-Added: The first measure of teacher quality, that can be computed for all teachers including newly hired teachers, is predicted teacher effectiveness. I obtain these by estimating an equation of student achievement with the inclusion of observable teacher characteristics (such as scores on the Praxis exams, certification etc.) on students in grades 3 through 5 for the years 1995 through 2006. Specifically I estimate [1] below.

$$
A_{i j g t}=\psi_{1} A_{i j g-1 t-1}+\psi_{2} \bar{A}_{i^{\prime} j g-1 t-1} \psi_{3} X_{i}+\psi_{4} Z_{s t}+\psi_{5} W_{j t}+\psi_{6} W_{j}+\tau_{t}+\tau_{g}+v_{j t}+\varepsilon_{i j g t}
$$

In [1] $A_{i j g t}$ is the achievement score of student $\mathrm{i}$ with teacher $\mathrm{j}$ in grade $\mathrm{g}$ in year $\mathrm{t}, \bar{A}_{i^{\prime} j g-1 t-1}$ are the average incoming test scores of a student's classmates, $X_{i}$ is a vector of student characteristics such as ethnicity, gender and parental education level. $W_{j t}$ is a vector including teacher experience and class-size, $Z_{s t}$ is a vector of school attributes including the percent black, percent

\footnotetext{
${ }^{9}$ Certification involves assessment of a teacher's classroom practices and content knowledge. The Praxis score is an average from a battery of standardized tests administered as part of the teacher licensing process.
} 
white, percent Hispanic, the percent free-lunch eligible students and the urbanicity of the school, $W_{j}$ is a vector of observable teacher characteristics, $\tau_{t}$ is a year fixed effect, $\tau_{g}$ is a grade fixed effect, $v_{j t}$ is a classroom level error term and $\varepsilon_{i j g t}$ is the idiosyncratic student level error term.

Using estimates from equation [1], I predict teacher effectiveness using the observable teacher characteristics. Specifically, the predicted value-added for teacher $\mathrm{j}$ is $\hat{\psi}_{6} W_{j}$ (i.e. the predicted value-added associated with teacher j's experience, certification, licensure test scores, college SAT scores, and advanced degree status). This measure serves as a useful summary statistic for all of the observable teacher characteristics. It is a weighted average of a teacher's observable characteristics, where the weights are determined by the characteristics' relationship with actual student achievement. The benefit of this measure is that it can be computed for all teachers irrespective of when they enter the data. Unfortunately, these measures are only defined for teachers in grades $\mathrm{K}$ through 5 . As such, it is important to note that both the measures pertain to teachers in elementary schools and not to teachers in middle schools and high schools. ${ }^{10}$ Estimated Value-Added: As the second measure I use a teacher's estimated value-added, estimated in an out-of-sample pre-period, as a characteristic. ${ }^{11}$ Specifically, to identify effective teachers, I estimate teacher fixed-effects in a test score growth model of the form [2] using data on students in grades 3 through 5 for the years 1995 through 1998.

$$
A_{i j g t}=\psi_{1} A_{i j g-1 t-1}+\psi_{2} \bar{A}_{i^{\prime} j g-1 t-1}+\psi_{3} X_{i}+\psi_{4} Z_{s t}+\psi_{5} W_{j t}+\tau_{g}+\left(\tau_{j}+\tau_{j t}+\varepsilon_{i j g t}\right)
$$

All variables are defined as before. There are no observable teacher characteristics included, and $\tau_{j}$ is a teacher fixed effect. Following Kane and Staiger (2008), I decompose the error term $\left(\tau_{j}+\tau_{j t}+\varepsilon_{i j g t}\right)$ to create Empirical Bayes (EB) estimates of the teacher value-added. ${ }^{12}$ To allow for estimates that are comparable across schools and grades, I do not include school or student fixed-effects but rather include a set of demographic controls for the students and schools. ${ }^{13}$

\footnotetext{
${ }^{10}$ Elementary schools make up 60 percent of all schools in North Carolina, so that this is a relevant population.

${ }^{11}$ While there are several specifications used in the literature to estimate teacher value-added, effects across studies are surprisingly robust to the chosen specification (Kane and Staiger 2008). For a detailed discussion of the theoretical and econometric assumptions underlying value-added specifications see Todd and Wolpin (2003).

${ }^{12}$ See appendix note 1 for details of how I compute the Empirical Baye's estimates.

${ }^{13}$ Specifications that include student or school fixed-effects identify teacher value-added based on within-school or within-student variation. If teachers are very different across schools, then much of the variation in teacher quality (i.e. the cross-school variation) will be absorbed by the school fixed-effect, making estimated effects across schools impossible to compare. Including student fixed-effects further exacerbates this problem by only allowing comparisons of teachers who teach the same groups of students. If those teachers who teach the gifted and talented
} 
To avoid endogeneity between charter entry and estimated value-added, when I analyze estimated value added, I exclude charter entry prior to $1998 .{ }^{14}$ One worry is that because the estimates are obtained only for teachers who are in the data prior to 1998, many teachers do not have estimated value added by 2006. Because about one quarter of teachers have estimated value-added in the analytical sample the estimates are sensitive to how missing data are treated. To bound the effects I present estimates that impute the 90th and 10th percentile of the valueadded distribution for teachers with no estimate. Also, because actual estimates are available for a minority of teachers, I rely more heavily on predicted value-added (above) as an outcome.

\section{II.3 Do Charter School Movers Differ From Those Who remain in TPSs?}

Since charter schools locate near traditional public schools that differ in important ways from the average school, there is no reason to expect that the teachers they attract will be representative of the state as a whole. To see how charter school movers compare to potential charter school applicants, I compare charter movers to the teachers at the schools they leave. To conduct this descriptive analysis, I estimate the following model by OLS.

$$
Y_{i j t}=\alpha+\beta \cdot \text { charter }_{i t}+\delta_{1} \cdot \text { Exit }_{i t}+\delta_{2} \cdot \text { Switch }_{i t}+\theta_{j t}+\varepsilon_{i j t}
$$

In [3] $\mathrm{Y}_{\mathrm{ijt}}$ is a characteristic of teacher $\mathrm{i}$ at school $\mathrm{j}$ in year $\mathrm{t}$, exit ${ }_{\mathrm{it}}$ is an indicator for whether teacher i leaves her current school at the end of academic year $t$, switch $_{\text {it }}$ is an indicator for whether the teacher moves to another North Carolina school in year $t+1$, charter $i_{i t}$ is an indicator for whether the teacher moves to a charter in year $\mathrm{t}+1$, and $\theta_{\mathrm{jt}}$ is a school-by-year fixed effect. The inclusion of a school-by-year fixed effect ensures that I compare teachers who leave for charter schools to teachers who worked at the same traditional public school in the previous year who did not switch to a charter school. The coefficients $\beta, \delta_{1}$, and $\delta_{2}$ estimate how departing teachers differ from the mean characteristics within a school-year cell. The sum of these coefficients, $\beta+\delta_{1}+\delta_{2}$, yields the difference in the characteristic between teachers moving to charter schools and teachers who did not leave their former schools during the year they left.

In Panel B of Table 4, compared to teachers at their previous schools, charter school movers have worse-than-average characteristics. The only characteristic in which charter school

\footnotetext{
students are of different average quality than those who teach the regular students, the estimated teacher value-added can only be used to compare teachers who share the same students so that comparing teachers who teach different students (even within the same school) may be misguided.

${ }^{14}$ Note that Jackson (2010) find that the teacher effectiveness if typically lower before a move to another school than after. As such theses estimated value-added may not perfectly represent long-run teacher effectiveness.
} 
movers appear better qualified than the average teacher at their former schools is mean Praxis score; however, this difference is not statistically significant from zero. The biggest differences between charter school movers and teachers at their old schools are in license status and experience. Charter school movers are $20.7 \%$ less likely to hold a state license and have 4.76 years fewer experience than teachers at the schools they leave behind - consistent with the characteristics of NC charter school teachers documented in Table 3. Looking at the measures of overall teacher quality, charter movers have 0.02 of a standard deviation lower predicted math value-added based on observable characteristics and 0.1 of a standard deviation lower estimated math value-added (both are statistically significant at the 5 percent level). Looking to reading, charter movers have 0.015 (albeit not significant) of a standard deviation lower predicted valueadded based on observable characteristics and 0.014 of a standard deviation lower estimated value-added. A notable pattern is that teachers who leave for charters differ from teachers who leave TPSs for other TPSs. Both math and reading value-added (imputed and estimated) are lower for charter switchers than traditional school switchers.

These comparisons describe teachers who switch from TPSs to charter schools, but they do not tell us how charter competition affects teachers at TPSs because teachers who moved to charters may have left TPSs absent charter competition. In the next section I detail a strategy to uncover an estimate of the effect of charter competition on teacher quality.

\section{Empirical Strategy}

The main obstacle to identifying the effect of charter entry is the non-random location of charter schools. Because charter schools locate near schools that differ from the average NC public school, a simple cross-school analysis is unlikely to yield a causal relationship. To avoid the bias that arises from non-random location decisions, I compare changes in outcomes within schools after an increase in charter competition to the change in outcomes within schools that face no changes in charter competition over the same time period. I implement this Difference in Difference (DID) strategy by estimating the following model by OLS.

$$
Y_{j t}=\alpha+\beta \cdot \text { nearby }_{j t}+\delta_{j}+\gamma_{t}+\varepsilon_{j t}
$$

$Y_{j t}$ is the mean teacher characteristic at school $j$ in year $t, \delta_{j}$ is a school fixed effect, $\gamma_{\mathrm{t}}$ is a year fixed effect, and nearby $y_{j t}$ is a measure of charter school competition. nearby $y_{j t}$ is an indicator variable denoting whether a charter school exists serving at least one common grade within a 
certain radius of school $j$ in year $t .^{15}$ Because it is not obvious ex ante what constitutes a "nearby" charter, I show estimates for having any charter school serving at least one common grade within 2 miles, 10 miles, and 20 miles. ${ }^{16}$ I use indicator variables for any nearby charter because most schools that face charter competition are only close to one charter. Figure 3 shows the distribution of the number of charters conditional on being close to any charter school for the three distance measures. Most of the variation in charter competition is between having zero and one nearby charter. In any case, results using the number of charters, or charter school enrolment, in a given area (not presented) are similar.

Because schools that face charter competition may differ in important unobserved ways from schools that do not, using all schools to form the counterfactual change in outcomes for schools that do face charter competition may be misguided. As such, I use as my sample only those schools that faced some charter competition during the sample period. ${ }^{17}$

This DID strategy removes (a) time-invariant differences in teacher characteristics specific to individual schools, and (b) time specific shocks (such as state-wide policies) that affect all schools. Using the sample of schools that face some charter competition, identification is based solely on variation in the timing of charter entry. As such, the remaining endogeneity concern is that having a charter school nearby is coincident with changes in unobserved characteristics that may affect staffing. Because this is a serious concern, I deal with the possibility of endogenous timing in a variety of ways. First, I estimate models that also include school-specific linear time trends; second, following Hanushek et al. (2007) and Imberman (2011), I provide interrupted panel estimates that remove data from the two years immediately preceding an increase in charter penetration; and finally I present visual evidence that the changes in outcomes occur after charter entry. The main findings are robust to making these adjustments, so that the findings can plausibly be given a causal interpretation.

As a further check on the results, I look at a subsample of schools for which I expect the largest effects. I identify 215 schools that are both in the top quarter of ethnic minority enrollment and percent minority because these two characteristics are associated with difficulty

\footnotetext{
${ }^{15}$ supporting this specification choice, while charter entry with at least one overlapping grade has statistically significant effects on outcomes, entry in non-overlapping grades has no effect.

${ }^{16}$ Bifulco and Ladd (2006) report that $89.7 \%$ of North Carolina charter student transfers come from a 10 mile radius of the schools. Loeb, Lankford and Wykoff show that teacher labor markets are very small so that the number of charter schools within 10 miles is likely the most relevant/appropriate measure of charter penetration.

${ }^{17}$ Note that using the full sample of schools makes little difference to the estimated results.
} 
retaining and attracting new teachers (Jackson 2009). ${ }^{18}$ If the proposed mechanisms are truly at play, one would expect that the estimated effects would be the most pronounced in these difficult to staff schools. Because these schools are also where resources are needed the most, the potential effects on students at these schools are of interest in their own right.

\section{Results}

In this section I present visual evidence to complement the regression estimates. Specifically, for each outcome I run a regression with four leads and lags of the charter entry variable, school fixed effects, and year fixed effects. I plot the estimated evolution of outcomes before and after charter entry and I present these plots along with the regression results.

\section{IV.1 Effects on Moving to Charter Schools and Exiting}

The top left panel of Figure 4 plots changes in the likelihood of exiting to a charter school before and after charter entry. Because charter schools did not exist before entry there must be a mechanical increase in teachers moving to a charter school after the entry of a charter school. Figure 4 shows that there is an increase in teachers moving to charter schools the year of charter entry within 2, 10, and 20 miles. The increase is most pronounced for charters within smaller distances - indicating that teachers tend to move to charters that are closest to their current school. A notable pattern is that while there is an initial increase in teachers moving to charters, this increase is short-lived so that the number of teachers moving to a charter school increases only slightly after about three years.

These patterns are consistent with the regression results. In the right panel of Table 5, I present coefficients on "nearby" charter for those within 2, 10 and 20 miles. The first row (school and year fixed effects) shows that having a charter within 2, 10, and 20 miles is associated with teachers being $0.15,0.12$, and 0.09 percentage points more likely to move to a charter school (all significant at the 1 percent level). To account for any pre-entry dip or spike in outcomes that might be associated with charter entry, in the second row I present interrupted panel estimates where data from the two years preceding charter entry are excluded. Such models yield point estimates that are very similar to those that include all years for the charter switching outcome. The third row presents interrupted panel estimates results while also including linear time trends

\footnotetext{
${ }^{18}$ These schools are primarily located in urban areas and have disproportionately low levels of students achievement, so that any reasonable classification of difficult to staff schools yields a similar set of schools and similar results.
} 
for each school to account for the fact that schools may have been on a trajectory of improving or deteriorating outcomes before charter entry. Results from this conservative specification are similar to the baseline DID estimates and show that charter entry within 2, 10, or 20 miles is associated with about a 0.1 percentage point increase in teachers moving to charter schools.

The effects on charter moving do not show that teachers left because of charter entry, so that one must look at the likelihood that a teacher leaves her school more broadly. The top right of figure 4 shows the likelihood that a teacher leaves her current school the following year. For 2 and 10 miles there appears to be a secular decline in teachers exiting the school, and little visual evidence of a change in exits associated with charter entry. For 20 miles the outcomes is relatively flat over time. This figure suggest that a failure to account for pre-existing trends may yield a spurious negative relationship between charter entry and teacher exits and that there is likely little or no causal relationship between charter entry and teacher exits. The regression results in Table 5 follow this pattern. For all distances, models that do not account for school trends show a negative relationship between charter entry and teacher exits, while models that account for trending and pre-entry spikes/dips in outcomes show that there is no systematic relationship between charter entry and teacher exits for schools on average.

Because I find that charter entry has virtually no effect of teacher exits on average, I now look to difficult to staff schools. Among difficult to staff schools, the point estimates suggest that there are little to no effects on teacher exits. The point estimates are positive for entry within two miles and negative for entry within 10 and 20 miles, and none of the estimates is significant at the 10 percent level. The lack of statistical significance and lack of robustness across models provide little evidence of increased turnover at difficult to staff schools.

While the theoretical framework suggests that the lack of any effect on teacher exit may be due to offsetting supply and demand shifts, readers may worry that the disruption in the teacher labor market from one additional charter is too small to affect teacher exits. To assess this, I focused on the 260 schools that saw more than one charter enter in one year. For these schools the point estimates are negative and statistically insignificant. I also look at the 18 difficult to staff school that had more than one charter enter at any time. In this sample the point estimate is very close to zero and is not statistically significant. As such, the results suggest that charter entry was not associated with an increase in turnover so that (a) supply pressure was experienced in the form of less hiring or (b) there were offsetting demand forces at play, or both. 


\section{IV.2 Effects on Salaries and New Hires}

In this section I look at the effect of charter entry on teacher salaries and the number of newly hired teachers. To avoid confounding changes in the composition of teachers at schools with the salaries paid to teachers I use the residual of the log of teacher salaries after taking out a fixed effect for each group defined by year, experience, license type, certification status, and degree. To ensure that composition effects do not drive the findings I verify that results that use teacher-level data and include teacher-by-school fixed effects (i.e. looking at changes in salary for the same teacher within the same school before and after charter entry) yield similar results.

The middle left panel of Figure 4 shows how the residual of log teacher salaries change before and after charter entry. For schools that face entry within 2 miles there is a secular decline in teacher pay from before charter entry and little evidence of any deviation from trend after charter entry. In contrast, for the 10 mile and 20 mile samples, teacher salaries appear to increase (relative to a slight upward pre-entry trend) after charter entry within 10 and 20 miles. The effect is visibly more pronounced for entry within 10 miles - indicating that charter entry within 10 miles may be the most appropriate dependent variable (i.e. entry within 2 miles misses much relevant variation and entry within 20 miles captures some irrelevant variation).

The regression results in Table 6 tell a similar story as the visuals in Figure 4. Across all specifications, there is no relationship between charter entry within 2 miles and teacher salaries. In contrast, charter entry within 10 miles is associated with statistically significant increases in teacher salaries in all specifications (except the model with trends that has large standard errors). The range of estimates indicate that charter entry within 10 miles is associated with between 0.25 and 0.37 of a percent increase in teacher pay. While the point estimates for the 20 miles sample are all positive (consistent with charter entry leading to an increase in teacher salaries) none of the coefficients is statistically significant. The fact that salary increases are largest for entry within 10 miles is consistent with research on teacher labor markets indicating that they are roughly 10 miles on radius (so that 2 miles is too narrow and 20 miles is too broad).

If the estimated effects are real, they should be more pronounced in difficult to staff schools. For all specifications, the effect of entry within 10 miles is larger in difficult to staff schools than on average. While the point estimates for all schools indicate that entry within 10 miles leads to between 0.25 and 0.37 of a percent increase in teacher pay, for the difficult to staff schools the estimates range between 1.2 and 1.3 percent (and are statistically significant). Again, 
it is entry within 10 miles that has the strongest effect- suggesting that 10 miles is the most appropriate radius. To support the salary results I look at the average number of paying positions a teacher holds in the school. If the increase in teacher pay is due, in part, to principals creating new positions, one should see an increase in this outcome associated with charter entry. Charter entry within 10 miles is associated with a statistically significant 3 percent increase in the mean number of paying positions held by teachers both for difficult to staff schools and all schools.

Looking to new hires, the middle right panel of Figure 4 shows how the natural log of the number of newly hired teachers changes before and after charter entry. For all distances (2, 10, 20 miles) charter entry is associated with a decline in new teacher hiring. As with the previous outcomes, the effect is more visibly pronounced for entry within 10 miles. The regression results in Table 6 tell a similar story. While charter entry within 2 miles has little effect on the number of new teachers hired, for all models charter entry within 10 miles and 20 miles is associated with a reduction in the number of new teachers hired. In the baseline specification charter entry within 10 and 20 miles is associated with statistically significant 6.2 and 5.8 percent declines in new teacher hiring, respectively. These results are robust to including linear trends for each school and dropping data for the years right before charter entry - suggestive of a real decline in new teacher hiring associated with charter entry within 10 and 20 miles.

As before, if the estimated effects are real, one would expect them to be more pronounced in difficult to staff schools. For all specifications, the decreases in new hires associated with entry within 10 and 20 miles are larger in difficult to staff schools than on average. The point estimates from the basic specification indicate that entry within 10, and 20 miles leads to a 11.6 and 9.1 percent decline in new hires at difficult to staff schools (both significant at the 5 percent level). Estimates from the more conservative model (school intercepts and trends and interrupted) are almost identical to the more basic model and are statistically significant at the 10 percent level - indicating a real sizable decline in new teacher hiring associated with charter entry within 10 and 20 miles at difficult to staff schools. As with the other outcomes, the effects are most pronounced for entry within 10 miles.

\section{IV.3 Effects on Teacher Quality}

Because charter entry may increase exits and leads to reduced hiring, charter entry might also lead to declines in overall teacher quality. Figure 4 plots predicted value-added (for all teachers including new hires) in math and reading before and after charter entry. There is a 
secular decline in teacher value-added for schools facing entry within two miles with no discernible shift at year zero. For entry within 10 and 20 miles the outcomes are relatively flat with slight declines three years after entry. It is also worth noting that the scale of these figures is sufficiently small that any effects are likely to be small. The regression estimates are consistent with this. In the regression results presented in Table 7, I focus on entry within 10 miles and present the effects on predicted value-added for the different models (on the left of each panel). While across all specifications there is a negative relationship between charter entry and predicted value-added for both reading and math, none of these effects is economically significant. That is, the largest effect for all schools indicates that charter entry within 10 miles is associated with less than 0.1 of a percent of standard deviation decline in teacher value-added.

There is a decline in teacher quality at difficult to staff schools associated with charter entry within 10 miles. As with the other outcomes the marginal effects are larger at these difficult to staff schools and the point estimates indicate charter entry reduced mean value-added in both subjects by between 0.15 and 0.32 of a percent of a standard deviation at difficult to staff schools. While the marginal effect of charter entry is more negative at difficult to staff schools for all specifications in both subjects (as with other outcomes) the effects are small.

To provide further evidence of a real decline in teacher quality at difficult to staff schools, I estimated the marginal effect of charter entry at each level of experience between 0 and 30. The results are presented in Figure 5. As one can see, charter entry is associated with statistically significant increases in the likelihood that a teacher has 0,1 , and 2 years of experience, but has little effect elsewhere in the experience distribution. This shows that the declines in teacher value added at schools that faced charter entry were driven largely by declines in teacher experience at the very bottom of the teacher experience distribution.

To complement the predicted value-added results, I also estimate effects on estimated value-added. As discussed previously, only about a quarter of teachers have estimated valueadded so that these estimates are only suggestive. To deal with missing data I estimate models where I impute the 90th and 10th percentiles of the estimated value-added distribution for math and reading to obtain upper and lower bound estimates. I present the results in Table 7. These results are consistent with those based on predicted value-added. In all models, irrespective of the value imputed for missing data, the effects for schools on average are close to zero and some estimates are negative while others are positive - suggesting little to no effect for the average 
school. In contrast, at difficult to staff schools, across all models, irrespective of the value imputed for missing data, the estimates are negative - suggesting a real decline in teacher effectiveness at difficult to staff schools. However, as with the predicted value-added the marginal effects, while statistically significant, are not economically significant.

\section{IV.4 Dynamic Effects over Time}

While the before/after analysis is informative, it might be instructive to see how outcomes evolve over time. Figure 6 shows new hires and salary (the two outcomes for which I find robust effects) four years before and after charter entry within 10 miles for all schools and difficult to staff schools. There is a persistent decline in new hires the year of charter entry for all schools and this decline is much larger in difficult to staff schools. On the right I show the effect on teacher salaries. There is an upward trend in teacher salaries at difficult to staff schools with evidence of an increase after charter entry, while for schools overall there is some evidence of an uptick in salaries after charter entry. The estimates for the turnover and value-added are sufficiently noisy that I do not present them visually but rely on the regression results.

Table 8 shows the estimated dynamic effects of charter entry within 10 miles for exit, moving to charter, compensation, new hires, and predicted value-added. I report the coefficients on the first and second lag of charter entry for the basic DID models and the conservative interrupted DID model with school trends. The point estimates for the conservative specification indicate that charter entry is associated with reductions in teacher turnover both overall and at difficult to staff schools. The results however are not statistically significant for difficult to staff schools. This suggests that in the long run there is no increase in teacher turnover associated with charter entry even at difficult to staff schools and that if anything, as a result of demand side pressure to retain teachers, teacher turnover may actually decline.

The conservative results for hiring and teacher pay suggest real persistent effects. At school on average three years after charter entry within 10 miles teacher salaries are 0.35 percent higher and the number of new hires is 11.3 percent lower. At difficult to staff schools teacher salaries are 3.39 percent higher three years after charter entry within 10 miles and the number of new hires is 16.9 percent lower - consistent with the large visible effects in Figure 6. The results for predicted value added suggest an initial decline in value-added for both math and reading that disappears over time such that three years after charter entry there is little to no difference in mean teacher value-added even at difficult to staff schools. Results for estimated value-added 
(not presented here) also suggest no long run effect on teacher effectiveness.

\section{IV.5 Who Receives Salary Increases?}

If school principals can identify those teachers that parents demand, and if these are the teachers principals chose to retain by giving them increased pay, one would expect that desirable teachers would experience the greater salary increases in schools facing charter entry. ${ }^{19}$ On the other hand, if principals aim to reduce turnover more generally schools may give pay increases to all teachers or to those teachers that are most mobile irrespective of their teaching ability. While I do not observe a teachers' desirability to parents, and I do not know what teacher characteristics principals consider desirable, I do have measures of teacher quality that arguably may be correlated with desirability for parents. I use these measures to see what kinds of teachers are systematically more likely to receive salary increases in those schools that face charter competition. Specifically, I use teacher level data and regress salary on charter entry and its interactions with estimated value-added, predicted value-added, experience, certification status, and math and science licensure (while including teacher-by-school fixed effects and year fixed effects). In such models (not presented) these interactions do not vary systematically across specifications and are not statistically significant - suggesting that those teachers that received increases in compensation were not necessarily the teachers I am able to identify as being effective or having characteristics that are associated with high value-added. This suggests that principals may be choosing to give teachers raises along dimensions other than those identified in these data. Given that personality traits and subjective evaluations, which are not necessarily correlated with estimated value-added, are predictive of subsequent student achievement (Rockoff and Speroni 2010), these findings do not mean that principals do not give raises to strong teachers, but that principals are not paying for the set of characteristics I have in the data. Moreover, insofar as principals may wish to reduce turnover overall, they may give raises to the most mobile teachers irrespective of their effectiveness or qualifications.

\section{Conclusions.}

Many education reforms such as school vouchers, school choice, and charter schools, are predicated, in part, on the notion that increased competitive pressures cause schools to use their

\footnotetext{
${ }^{19}$ In a recent paper Hensvik (2010) uses a reform in Sweden that created regional variation in private school entry and find that high ability teachers in math and science receive 4 percent higher wages in the most competitive areas.
} 
scarce resources more efficiently. However, some view the education system as operating with fixed inputs so that competing schools influence outcomes by redistributing resources within the education system and may reduce the resources available to TPSs. Unfortunately, there is no consensus on whether school competition helps or hurts students at incumbent schools.

I shed light on this issue by investigating one possible mechanism. Specifically, I identify the effect of charter school competition on the labor market for TPS teachers. I find that teachers moving from TPSs to charter schools have below-average qualifications, but contrary to common belief, schools that face increased charter school competition do not experience any long-run increases in teacher turnover. This suggests that charter schools merely provide alternative employment for less effective teachers who would have left TPS absent charter entry. I do however find evidence of competitive supply side pressure such that schools that face charter entry experience declines in the number of new teachers hired. I also find that schools that face charter entry increase teacher pay - indicative of a demand side response to better attract and retain teachers. Consistent with these being the results of competitive pressure, I find that these effects are more pronounced in difficult to staff schools. I also found evidence of very slight declines in teacher quality associated with charter entry at these difficult to staff schools.

The results suggest that worries that school competition may lead to the siphoning off of the best teachers away from traditional public schools may be unfounded for most schools, but may be a cause for concern at difficult to staff schools. Since increased teacher pay must come at the expense of other expenditures, the increases in teacher pay (which are non-trivial) imply that competition in the labor market for teachers led to reduced expenditures on other potentially productive inputs. As such, while charter competition may have a negligible effect (through its effect on teacher labor markets) on students at desirable schools, students at difficult to staff schools may experience increased unfilled vacancies, reduced expenditure on non-teaching inputs, and lower quality instruction. These heterogeneous effects on teacher labor markets underscore the importance of thinking about both teacher supply and demand and may help explain the varied findings on the effect of charter competition on student outcomes. 


\section{References.}

Aaronson, Daniel, Lisa Barrow and William Sander. 2007. "Teachers and Student Achievement in the Chicago Public High Schools.” Journal of Labor Economics, 25(1): 95-135.

Baker, Bruce D. and Jill L. Dickerson. 2006. “Charter Schools, Teacher Labor Market Deregulation, and Teacher Quality: Evidence From the Schools and Staffing Survey.” Educational Policy, 20(5): 752-778.

Barbour, Elisa. Deborah Reed, and Kim S. Rueben, "Retention of new teachers in California" Public Policy Institute of CA, 2006.

Bettinger, Eric P. 2005. "The Effect of Charter Schools on Charter Students and Public Schools.” Economics of Education Review, 24: 133-147.

Bifulco, Robert and Helen F. Ladd. 2006. "The Impacts of Charter Schools on Student Achievement: Evidence from North Carolina.” Education Finance and Policy, 1(1):50-90.

Boyd, Donald, Hamilton Lankford, Susanna Loeb and James Wyckoff. 2005. "The Draw of Home: How Teachers’ Preferences for Proximity Disadvantage Urban Schools.” Journal of Policy Analysis and Management, 24(1): 113-132.

Burian-Fitzgerald, Marisa and Debbi Harris. 2004. "Teacher Recruitment and Teacher Quality? Are Charter Schools Different?” Education Policy Center at Michigan State University.

Carruthers, Celeste. 2009. "The Qualifications and Classroom Performance of Teachers Moving to Charter Schools.” Working paper no. 27. National Center for Analysis of Longitudinal Data in Education Research.

Charter Schools Act of 1996. 1995. North Carolina General Statutes ch. 115C, § 238.29.

Clotfelter, Charles T., Helen F. Ladd and Jacob L. Vigdor. 2007. “Teacher Credentials and Student Achievement in High School: A Cross-Subject Analysis with Student Fixed Effects.” NBER Working paper no. 13617.

Dee, Thomas S. 1998. “Competition and the Quality of Public Schools.” Economics of Education Review, 17(4): 419-427.

Ehrenberg, Ronald G. and Dominic J. Brewer. 1994. "Do School and Teacher Characteristics Matter?” Economics of Education Review, 13(1): 78-99.

Fallis, Davd S. and Dan Keating. 2008, December 15. “D.C. Prep’s Founder Emphasizing Financing, Staff.” The Washington Post.

Friedman, M. (1955): “The Role of Government in Education,” in Economics and the Public Interest, ed. by R. Solow, New Brunswick, NJ: Rutgers University. (1997): “Public Schools: Make Them Private,” Education Economics, 5, 341-345.

Gootman, Elissa. 2008, March 7. “At Charter School, Higher Teacher Pay.” The New York Times.

Hanushek, Eric A., John F. Kain, Daniel M. O’Brien and Steven G. Rivkin. 2005. “The Market for Teacher Quality.” NBER Working paper no. 11154.

Hanushek, Eric, John Kain, Steven Rivkin and Gregory Branch. 2007. "Charter School Quality and Parental Decision Making with School Choice.” Journal of Public Economics, 91: 823-848.

Hanushek, Eric and Steven Rivkin, “Does Public School Competition Affect Teacher Quality?,” in The Economic Analysis of School Choice, ed. by Caroline Hoxby, University of Chicago Press, 2003.

Hensvik, Lena. 2010. "Employer Competition and Wages: Lessons Learned from Swedish Teachers" Working paper

Hoxby, Caroline M. 2000. “Does Competition among Public Schools Benefit Students and 
Taxpayers?” The American Economic Review, 90(5): 1209-1238.

Hoxby, Caroline M. 2002. "Would School Choice Change the Teaching Profession?” The Journal of Human Resources, 37(4): 846-891.

Hoxby, Caroline M. 2007. "Does Competition Among Public Schools Benefit Students and

Taxpayers? Reply.” The American Economic Review, 97(5): 2038-2055.

Imberman, Scott. 2011. "Achievement and Behavior in Charter Schools: Drawing a More

Complete Picture.” Review of Economics and Statistics, 93(2).

Imberman, Scott. 2009. "The Effect of Charter Schools on Achievement and Behavior of Public

School Students." Unpublished manuscript.

Jackson, C. Kirabo. 2009. "Student Demographics, Teacher Sorting, and Teacher Quality:

Evidence from the End of Desegregation.” Journal of Labor Economics, 27(2): 213-256.

Jackson, C. Kirabo and Elias Bruegmann. 2009. "Teaching Students and Teaching Each Other:

The Importance of Peer Learning for Teachers.” American Economic Journal: Applied

Economics 1(4): 85-108.

Jackson, C. Kirabo. 2010. "Match Quality, Worker Productivity, and Worker Mobility: Direct

Evidence From Teachers," NBER Working Papers 15990,

Kane, Thomas J. and Douglas O. Staiger. 2008. "Estimating Teacher Impacts on Student

Achievement: An Experimental Evaluation.” NBER Working paper no. 14607.

Keating, Dan and Theola Labbe-DeBose. 2008, December 15. "Charter Schools Make Gains on Tests.” The Washington Post.

Martin, R. (2000). Local labor markets: Their nature, performance, and regulation. In G. Clark, M. Feldman, \& M. Gerthler (Eds.), The Oxford handbook of economic geography. Oxford University Press.

Murnane, Richard and J. Jennifer L. Steele "What Is the Problem? The Challenge of Providing Effective Teachers for All Children" Excellence in the Classroom Volume 17 Number 1 Spring 2007.

North Carolina Department of Public Instruction. 2009. "Fiscal Year 2009-2010 North Carolina Public Schools Salary Schedules.” Raleigh, NC.

Podgursky, Michael and Dale Ballou. 2001. "Personnel Policy in Charter Schools.” Washington, D.C.: Thomas B. Fordham Foundation.

Rivkin, Steven G., Eric A. Hanushek and John F. Kain. 2005. "Teachers, Schools, and Academic Achievement.” Econometrica, 73(2): 417-458.

Rockoff, Jonah E. 2004. "The Impact of Individual Teachers on Student Achievement: Evidence from Panel Data.” The American Economic Review, 94(2): 247-252.

Rockoff, Jonah E. and Cecilia Speroni "Subjective and Objective Evaluations of Teacher Effectiveness: Evidence from New York City" Columbia University mimeo.

Matthew Ronfeldt, Hamilton Lankford, Susanna Loeb, James Wyckoff, (2011) "How Teacher

Turnover Harms Student Achievement” Working Paper

Rothstein, Jesse. 2007. "Does Competition Among Public Schools Benefit Students and Taxpayers? Comment.” The American Economic Review, 97(5): 2026-2037.

Sass, Tim R. 2006. "Charter Schools and Student Achievement in Florida.” Education Finance and Policy, 1(1): 91-122.

Todd, Petra E. and Kenneth I. Wolpin. 2003. "On the Specification and Estimation of the Production Function for Cognitive Achievement.” The Economic Journal, 113: F3-F33.

Vedder, Richard and Joshua Hall. 2000. "Private School Competition and Public School Teacher Salaries.” Journal of Labor Research, 21(1): 161-168. 


\section{Tables and Figures}

Table 1: Charter Entry and Turnover by Year.

\begin{tabular}{|c|c|c|c|c|c|c|c|c|c|}
\hline & 1997 & 1998 & 1999 & 2000 & 2001 & 2002 & 2003 & 2004 & 2005 \\
\hline \multicolumn{10}{|c|}{ Charter school entrance } \\
\hline Openings & 34 & 26 & 23 & 15 & 8 & 5 & 2 & 5 & 2 \\
\hline Closings & 0 & 1 & 5 & 2 & 5 & 5 & 2 & 1 & 0 \\
\hline Total charters & 34 & 59 & 77 & 90 & 93 & 93 & 93 & 97 & 99 \\
\hline \multicolumn{10}{|c|}{ Teacher turnover, all schools } \\
\hline Number of teachers & 71392 & 73181 & 75455 & 77206 & 79041 & 80488 & 82557 & 84870 & 86346 \\
\hline Exiting & 13172 & 14554 & 14997 & 16228 & 16195 & 16574 & 16036 & 16798 & 19001 \\
\hline Exiting to charter & 81 & 94 & 89 & 120 & 118 & 94 & 100 & 148 & 155 \\
\hline Pct. exiting to charter & $0.11 \%$ & $0.13 \%$ & $0.12 \%$ & $0.16 \%$ & $0.15 \%$ & $0.12 \%$ & $0.12 \%$ & $0.17 \%$ & $0.18 \%$ \\
\hline \multicolumn{10}{|c|}{ Teacher turnover, schools w/in 2 mi. of a charter } \\
\hline Number of teachers & 1965 & 4286 & 5971 & 7113 & 7252 & 7620 & 7645 & 8830 & 8688 \\
\hline Exiting & 394 & 1025 & 1332 & 1717 & 1721 & 1747 & 1780 & 1884 & 2174 \\
\hline Exiting to charter & 13 & 17 & 22 & 19 & 23 & 13 & 21 & 35 & 39 \\
\hline Pct. exiting to charter & $0.66 \%$ & $0.40 \%$ & $0.37 \%$ & $0.27 \%$ & $0.32 \%$ & $0.17 \%$ & $0.27 \%$ & $0.40 \%$ & $0.45 \%$ \\
\hline \multicolumn{10}{|c|}{ Teacher turnover, schools 2-10 mi. from a charter } \\
\hline Number of teachers & 12089 & 18939 & 24225 & 27038 & 30245 & 32332 & 33001 & 33937 & 37252 \\
\hline Exiting & 2422 & 3853 & 4957 & 5935 & 6314 & 6965 & 6416 & 6568 & 8461 \\
\hline Exiting to charter & 28 & 40 & 33 & 54 & 52 & 56 & 46 & 73 & 88 \\
\hline Pct. exiting to charter & $0.23 \%$ & $0.21 \%$ & $0.14 \%$ & $0.20 \%$ & $0.17 \%$ & $0.17 \%$ & $0.14 \%$ & $0.22 \%$ & $0.24 \%$ \\
\hline \multicolumn{10}{|c|}{ Teacher turnover, schools 10-20 mi. from a charter } \\
\hline Number of teachers & 11150 & 20648 & 20961 & 20838 & 21064 & 20428 & 20543 & 20363 & 20415 \\
\hline Exiting & 2043 & 3934 & 4153 & 4115 & 4123 & 3751 & 3790 & 3538 & 4193 \\
\hline Exiting to charter & 11 & 17 & 23 & 27 & 29 & 16 & 21 & 26 & 18 \\
\hline Pct. exiting to charter & $0.10 \%$ & $0.08 \%$ & $0.11 \%$ & $0.13 \%$ & $0.14 \%$ & $0.08 \%$ & $0.10 \%$ & $0.13 \%$ & $0.09 \%$ \\
\hline \multicolumn{10}{|c|}{ Charter teachers } \\
\hline Total & 307 & 566 & 843 & 1052 & 1259 & 1352 & 1489 & 1649 & 1766 \\
\hline Previously in TPS & 171 & 279 & 405 & 494 & 568 & 606 & 614 & 686 & 680 \\
\hline Percent previously in & 55.70 & 49.29 & 48.04 & 46.96 & 45.12 & 44.82 & 41.24 & 41.60 & 38.51 \\
\hline
\end{tabular}


Table 2: Summary Statistics for All Public Schools, Charter Schools, and Schools that Face Charter Competition.

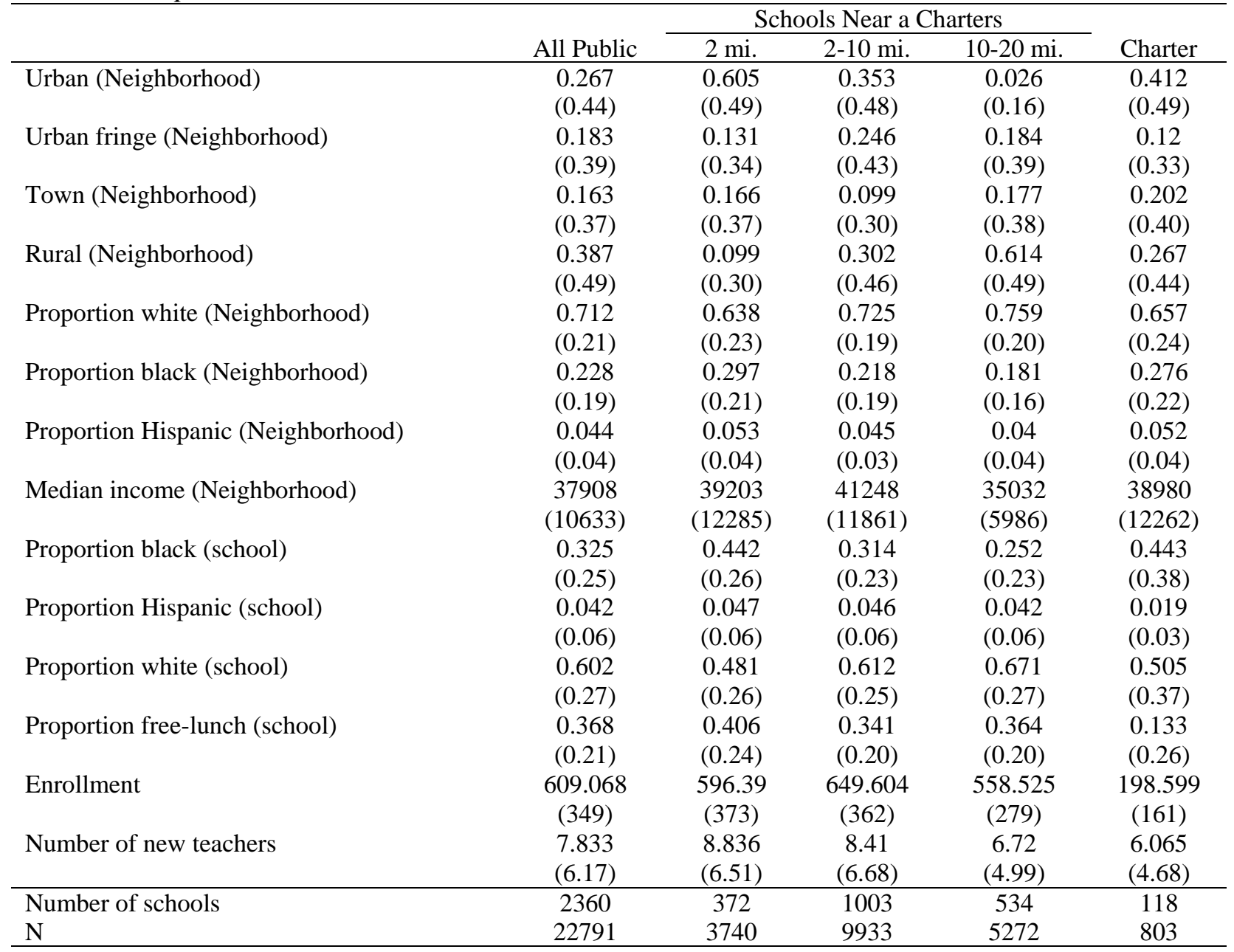

Standard deviations in parentheses. Observations are at the school-by-year level. Near charter consists of schools within a given distance of a charter school. 
Table 3: Summary Statistics (Teachers).

\begin{tabular}{|c|c|c|c|c|c|c|c|}
\hline & \multirow[b]{2}{*}{ All Public } & \multicolumn{3}{|c|}{ Schools Near a Charter } & \multicolumn{3}{|c|}{ All Movers } \\
\hline & & 2 miles & 2-10 miles & 10-20 miles & Exiters & Movers & CS Movers \\
\hline \multirow[t]{2}{*}{ NB Certification } & 0.034 & 0.041 & 0.048 & 0.04 & 0.021 & 0.031 & 0.015 \\
\hline & $(0.18)$ & $(0.20)$ & $(0.21)$ & $(0.20)$ & $(0.14)$ & $(0.17)$ & $(0.12)$ \\
\hline \multirow[t]{2}{*}{ Licensed } & 0.829 & 0.804 & 0.827 & 0.825 & 0.686 & 0.804 & 0.537 \\
\hline & $(0.38)$ & $(0.40)$ & $(0.38)$ & $(0.38)$ & $(0.46)$ & $(0.40)$ & $(0.50)$ \\
\hline \multirow[t]{2}{*}{ Advanced Degree } & 0.318 & 0.316 & 0.313 & 0.3 & 0.32 & 0.283 & 0.245 \\
\hline & $(0.47)$ & $(0.47)$ & $(0.46)$ & $(0.46)$ & $(0.47)$ & $(0.45)$ & $(0.43)$ \\
\hline \multirow[t]{2}{*}{ SATM75 } & 582.436 & 580.814 & 587.295 & 584.202 & 584.151 & 582.23 & 578.857 \\
\hline & $(59.70)$ & $(67.88)$ & $(60.68)$ & $(53.77)$ & $(62.58)$ & $(60.00)$ & $(66.65)$ \\
\hline \multirow[t]{2}{*}{ Experience } & 13.494 & 12.952 & 12.946 & 13.447 & 13.014 & 10.117 & 12.768 \\
\hline & $(10.36)$ & $(10.74)$ & $(10.39)$ & $(10.49)$ & (12.53) & $(9.84)$ & $(14.20)$ \\
\hline \multirow[t]{2}{*}{ Std. License Score } & 0.033 & 0.048 & 0.094 & 0.039 & 0.052 & 0.02 & 0.029 \\
\hline & $(0.89)$ & $(0.90)$ & $(0.86)$ & $(0.85)$ & $(0.88)$ & $(0.87)$ & $(0.95)$ \\
\hline \multirow[t]{2}{*}{ Female } & 0.802 & 0.823 & 0.828 & 0.806 & 0.788 & 0.803 & 0.8 \\
\hline & $(0.40)$ & $(0.38)$ & $(0.38)$ & $(0.40)$ & $(0.41)$ & $(0.40)$ & $(0.40)$ \\
\hline \multirow[t]{2}{*}{ Black } & 0.146 & 0.236 & 0.151 & 0.108 & 0.167 & 0.157 & 0.267 \\
\hline & $(0.35)$ & $(0.43)$ & $(0.36)$ & $(0.31)$ & $(0.37)$ & $(0.36)$ & $(0.44)$ \\
\hline \multirow[t]{2}{*}{ White } & 0.835 & 0.745 & 0.832 & 0.869 & 0.808 & 0.823 & 0.701 \\
\hline & $(0.37)$ & $(0.44)$ & $(0.37)$ & $(0.34)$ & $(0.39)$ & $(0.38)$ & $(0.46)$ \\
\hline \multirow[t]{2}{*}{ Predicted Math VA } & 0.15 & 0.147 & 0.151 & 0.151 & 0.14 & 0.143 & 0.127 \\
\hline & $(0.03)$ & $(0.04)$ & $(0.03)$ & $(0.03)$ & $(0.04)$ & $(0.03)$ & $(0.04)$ \\
\hline \multirow[t]{2}{*}{ Predicted Reading VA } & 0.066 & 0.063 & 0.065 & 0.066 & 0.058 & 0.059 & 0.048 \\
\hline & $(0.02)$ & $(0.03)$ & $(0.03)$ & $(0.02)$ & $(0.03)$ & $(0.02)$ & $(0.03)$ \\
\hline \multirow[t]{2}{*}{ Estimated Math VA } & -0.044 & -0.042 & -0.04 & -0.048 & -0.05 & -0.05 & -0.056 \\
\hline & $(0.17)$ & $(0.17)$ & $(0.17)$ & $(0.18)$ & $(0.19)$ & $(0.22)$ & $(0.20)$ \\
\hline \multirow[t]{2}{*}{ Estimated Reading VA } & -0.009 & -0.01 & -0.008 & -0.01 & -0.01 & -0.01 & -0.012 \\
\hline & $(0.07)$ & $(0.06)$ & $(0.08)$ & $(0.06)$ & $(0.08)$ & $(0.08)$ & $(0.07)$ \\
\hline \multirow[t]{2}{*}{ Exit } & 0.203 & 0.237 & 0.215 & 0.197 & 1 & 1 & 1 \\
\hline & $(0.40)$ & $(0.43)$ & $(0.41)$ & $(0.40)$ & - & - & - \\
\hline \multirow[t]{2}{*}{ Move to charter } & 0.001 & 0.003 & 0.002 & 0.001 & 0.007 & 0.019 & 1 \\
\hline & $(0.04)$ & $(0.06)$ & $(0.04)$ & $(0.03)$ & $(0.08)$ & $(0.14)$ & - \\
\hline $\mathrm{N}$ & 822286 & 58012 & 241825 & 171000 & 170353 & 60335 & 1120 \\
\hline
\end{tabular}

Standard errors in parentheses. Observations are at the teacher by school level. Exiters consists of teachers leaving the NC school system altogether; Movers are teachers leaving for another NC traditional public school; and CS Movers are teachers leaving for an NC charter. 
Table 4: Comparison of Moving Teachers.

\begin{tabular}{|c|c|c|c|c|c|c|c|c|c|c|}
\hline & \multirow[b]{2}{*}{ NB Cert. } & \multirow[b]{2}{*}{ Lic. } & \multirow[b]{2}{*}{ Exp. } & \multirow[b]{2}{*}{ Adv. Deg. } & \multirow[b]{2}{*}{ SATM75 } & \multirow[b]{2}{*}{ Praxis } & \multicolumn{2}{|c|}{ Predicted VA } & \multicolumn{2}{|c|}{ Estimated VA } \\
\hline & & & & & & & Math VA & Read VA & Math VA & Read VA \\
\hline \multicolumn{11}{|c|}{ Panel A. Year fixed effects only. } \\
\hline Leave current school & $-0.021 * *$ & $-0.211^{* *}$ & $0.157^{*}$ & $0.022^{* *}$ & $3.496^{* *}$ & $0.043^{* *}$ & $-0.015^{* *}$ & $-0.011 * *$ & $-0.008 * *$ & $-0.002 * *$ \\
\hline \multirow[t]{2}{*}{ Switch schools } & $0.017^{* *}$ & $0.181^{* *}$ & $-4.196 * *$ & $-0.056^{* *}$ & $-3.001 * *$ & $-0.054 * *$ & $0.007^{* *}$ & $0.003^{* *}$ & 0 & 0 \\
\hline & {$[0.001]$} & {$[0.003]$} & {$[0.091]$} & {$[0.003]$} & {$[0.446]$} & {$[0.006]$} & 0.000 & 0.000 & {$[0.002]$} & {$[0.001]$} \\
\hline Move to charter & $-0.022 * *$ & $-0.184 * *$ & -0.416 & $-0.027+$ & $-5.222 *$ & -0.005 & $-0.015^{* *}$ & $-0.009 * *$ & -0.007 & -0.001 \\
\hline Charter movers - stayers & $-0.025 * *$ & $-0.215^{* *}$ & $-4.454 * *$ & $-0.062 * *$ & $-4.727^{*}$ & -0.016 & $-0.023 * *$ & $-0.018 * *$ & -0.015 & -0.002 \\
\hline Std. Err. & {$[0.005]$} & {$[0.018]$} & {$[0.410]$} & {$[0.016]$} & [2.644] & {$[0.036]$} & {$[0.002]$} & {$[0.002]$} & {$[0.010]$} & {$[0.004]$} \\
\hline $\mathrm{N}$ & 737416 & 714117 & 737416 & 720351 & 672533 & 675058 & 340855 & 340855 & 340855 & 340855 \\
\hline \multicolumn{11}{|c|}{ Panel B. School-by-year fixed effects. } \\
\hline Switch schools & {$[0.001]$} & {$[0.003]$} & {$[0.088]$} & {$[0.003]$} & {$[0.376]$} & {$[0.005]$} & 0.000 & 0.000 & {$[0.002]$} & {$[0.001]$} \\
\hline \multirow[t]{2}{*}{ Move to charter } & $-0.018 * *$ & $-0.178 * *$ & 0.007 & -0.018 & $-5.537 *$ & -0.001 & $-0.013^{* *}$ & $-0.008 * *$ & -0.01 & 0 \\
\hline & {$[0.005]$} & {$[0.018]$} & [0.402] & {$[0.016]$} & {$[2.506]$} & {$[0.034]$} & {$[0.002]$} & {$[0.002]$} & {$[0.010]$} & {$[0.004]$} \\
\hline Charter movers - stayers & $-0.020 * *$ & $-0.207 * *$ & $-3.776 * *$ & $-0.040^{*}$ & -0.944 & 0.039 & $-0.019 * *$ & $-0.015^{* *}$ & $-0.018+$ & -0.002 \\
\hline Std. Err. & {$[0.005]$} & {$[0.017]$} & [0.397] & {$[0.016]$} & [2.492] & {$[0.034]$} & {$[0.002]$} & {$[0.002]$} & {$[0.010]$} & {$[0.004]$} \\
\hline $\mathrm{N}$ & 737416 & 714117 & 737416 & 720351 & 672533 & 675058 & 340855 & 340855 & 340855 & 340855 \\
\hline
\end{tabular}


Table 5: Effect of Charter Entry on Teacher Mobility.

Dependent Variable: Exit current school

\begin{tabular}{cccccc}
\hline \multicolumn{5}{c}{ Basic DID with School and Year Fixed Effects } \\
\hline \multicolumn{2}{c}{2 miles } & \multicolumn{2}{c}{10 miles } & \multicolumn{2}{c}{20 miles } \\
\hline $\begin{array}{c}\text { All } \\
\text { Schools }\end{array}$ & $\begin{array}{c}\text { Difficult } \\
\text { to Staff }\end{array}$ & $\begin{array}{c}\text { All } \\
\text { Schools }\end{array}$ & $\begin{array}{c}\text { Difficult } \\
\text { to Staff }\end{array}$ & $\begin{array}{c}\text { All } \\
\text { Schools }\end{array}$ & $\begin{array}{c}\text { Difficult } \\
\text { to Staff }\end{array}$ \\
\hline-0.00368 & 0.00559 & $-0.01132 * *$ & -0.01107 & $-0.00647^{*}$ & -0.00879 \\
{$[0.00725]$} & {$[0.01880]$} & {$[0.00329]$} & {$[0.01083]$} & {$[0.00322]$} & {$[0.00827]$} \\
3119 & 725 & 14339 & 2021 & 20504 & 2,827
\end{tabular}

Interrupted with School and Year Fixed Effects

\begin{tabular}{lcccccc} 
& \multicolumn{6}{c}{ Interrupted with School and Year Fixed Effects } \\
\cline { 2 - 7 } Nearby & -0.00212 & 0.00851 & $-0.01089 * *$ & -0.01624 & -0.00558 & -0.01034 \\
se & {$[0.00760]$} & {$[0.02037]$} & {$[0.00349]$} & {$[0.01192]$} & {$[0.00344]$} & {$[0.00884]$} \\
Obs. & 2569 & 603 & 11745 & 1681 & 16774 & 2353 \\
\hline
\end{tabular}

Interrupted with Trends and School and Year Fixed Effects

\begin{tabular}{lcccccc}
\cline { 2 - 6 } Nearby & -0.00049 & 0.01503 & -0.004238 & -0.005109 & -0.00701 & -0.01522 \\
se & {$[0.00908]$} & {$[0.01986]$} & {$[0.00511]$} & {$[0.01341]$} & {$[0.00402]$} & {$[0.01092]$} \\
Obs. & 2569 & 603 & 11745 & 1681 & 16774 & 2353 \\
\hline
\end{tabular}

The indicator variable " Nearby " is equal to 1 if a charter school with at least one
Robust standard errors in brackets are adjusted for clustering at the school level.
$* * \mathrm{p}<0.01,{ }^{*} \mathrm{p}<0.05,+\mathrm{p}<0.1$

Dependent Variable: Switch to a charter school Basic DID with School and Year Fixed Effects

\begin{tabular}{cccccc}
\hline \multicolumn{2}{c}{2 miles } & \multicolumn{2}{c}{10 miles } & \multicolumn{2}{c}{20 miles } \\
\hline $\begin{array}{c}\text { All } \\
\text { Schools }\end{array}$ & $\begin{array}{c}\text { Difficult } \\
\text { to Staff }\end{array}$ & $\begin{array}{c}\text { All } \\
\text { Schools }\end{array}$ & $\begin{array}{c}\text { Difficult } \\
\text { to Staff }\end{array}$ & $\begin{array}{c}\text { All } \\
\text { Schools }\end{array}$ & $\begin{array}{c}\text { Difficult } \\
\text { to Staff }\end{array}$ \\
\hline $0.00148^{*}$ & 0.00207 & $0.00122^{* *}$ & $0.00195^{*}$ & $0.00092^{* *}$ & $0.00194^{* *}$ \\
{$[0.00067]$} & {$[0.00243]$} & {$[0.00037]$} & {$[0.00094]$} & {$[0.00019]$} & {$[0.00075]$} \\
3119 & 725 & 14339 & 2021 & 20504 & 2827 \\
\hline
\end{tabular}

Interrupted with School and Year Fixed Effects

\begin{tabular}{cccccc}
\hline 0.00101 & -0.00058 & $0.00124^{* *}$ & 0.00144 & $0.00088^{* *}$ & $0.00147+$ \\
{$[0.00084]$} & {$[0.00326]$} & {$[0.00045]$} & {$[0.00098]$} & {$[0.00019]$} & {$[0.00075]$} \\
2569 & 603 & 11745 & 1681 & 16774 & 2353 \\
\hline
\end{tabular}

Interrupted with Trends and School and Year Fixed Effects

\begin{tabular}{cccccc}
0.001 & -0.00046 & $0.00112+$ & 0.00113 & $0.00089 * *$ & $0.00154+$ \\
{$[0.00093]$} & {$[0.00305]$} & {$[0.00063]$} & {$[0.00127]$} & {$[0.00032]$} & {$[0.00093]$} \\
2569 & 603 & 11745 & 1681 & 16774 & 2353 \\
\hline
\end{tabular}

verlapping grade is located within the prescribed distance of the TPS and 0 otherwise. 
Table 6: Effect of Charter Entry on Teacher Pay and New Hiring.

Dependent Variable: Log number of new hires

\begin{tabular}{cccccc}
\hline \multicolumn{5}{c}{ Basic DID with School and Year Fixed Effects } \\
\hline \multicolumn{2}{c}{2 miles } & \multicolumn{2}{c}{10 miles } & \multicolumn{2}{c}{20 miles } \\
\hline $\begin{array}{c}\text { All } \\
\text { Schools }\end{array}$ & $\begin{array}{c}\text { Difficult } \\
\text { to Staff }\end{array}$ & $\begin{array}{c}\text { All } \\
\text { Schools }\end{array}$ & $\begin{array}{c}\text { Difficult to } \\
\text { Staff }\end{array}$ & $\begin{array}{c}\text { All } \\
\text { Schools }\end{array}$ & $\begin{array}{c}\text { Difficult } \\
\text { to Staff }\end{array}$ \\
\hline-0.02135 & -0.01721 & $-0.06187^{* *}$ & $-0.11604^{*}$ & $-0.05778^{* *}$ & $-0.09075^{*}$ \\
{$[0.03847]$} & {$[0.08456]$} & {$[0.01930]$} & {$[0.05517]$} & {$[0.01764]$} & {$[0.04361]$} \\
2841 & 667 & 13022 & 1855 & 18632 & 2596
\end{tabular}

\begin{tabular}{lcccccc} 
Observations & 2841 & 667 & 13022 & 1855 & 18632 & 2596 \\
\hline \multirow{7}{*}{ Nearby } & -0.02558 & -0.01515 & $-0.06493^{* *}$ & $-0.16504^{* *}$ & $-0.06600^{* *}$ & $-0.11436^{*}$ \\
se & {$[0.03878]$} & {$[0.09113]$} & {$[0.02059]$} & {$[0.05920]$} & {$[0.01902]$} & {$[0.04784]$} \\
Obs. & 2323 & 553 & 10608 & 1551 & 15046 & 2144 \\
\hline
\end{tabular}

\begin{tabular}{lcccccc} 
& \multicolumn{7}{c}{15046} & 2144 \\
\cline { 2 - 7 } Nearby & 0.00055 & 0.01983 & $-0.08705^{* *}$ & $-0.14712^{* *}$ & $-0.07725^{* *}$ & $-0.09670+$ \\
se & {$[0.04550]$} & {$[0.09816]$} & {$[0.03021]$} & {$[0.05490]$} & {$[0.02302]$} & {$[0.05065]$} \\
Obs. & 2323 & 553 & 10608 & 1551 & 15046 & 2144 \\
\hline
\end{tabular}

Dependent Variable: Log residual salary

\begin{tabular}{cccccc}
\hline \multicolumn{5}{c}{ Basic DID with School and Year Fixed Effects } \\
\hline \multicolumn{2}{c}{2 miles } & \multicolumn{2}{c}{10 miles } & \multicolumn{2}{c}{20 miles } \\
\hline All & Difficult & All & Difficult & All & Difficult \\
Schools & to Staff & Schools & to Staff & Schools & to Staff \\
\hline 0.00301 & -0.0004 & $0.00367^{* *}$ & $0.01265^{* *}$ & 0.00158 & 0.00312 \\
{$[0.00273]$} & {$[0.00779]$} & {$[0.00133]$} & {$[0.00461]$} & {$[0.00130]$} & {$[0.00463]$} \\
3118 & 725 & 14337 & 2021 & 20502 & 2827 \\
\hline
\end{tabular}

\begin{tabular}{cccccc}
\multicolumn{7}{c}{ Interrupted with School and Year Fixed Effects } \\
\hline 0.00155 & -0.00333 & $0.00277^{*}$ & $0.01344^{* *}$ & 0.00167 & 0.00365 \\
{$[0.00303]$} & {$[0.00850]$} & {$[0.00141]$} & {$[0.00508]$} & {$[0.00133]$} & {$[0.00481]$} \\
2323 & 553 & 10608 & 1551 & 15046 & 2144 \\
\hline
\end{tabular}

\begin{tabular}{cccccc}
2323 & 553 & 10608 & 1551 & 15046 & 2144 \\
\hline \multicolumn{7}{c}{ Interrupted with Trends and School and Year Fixed Effects } \\
\hline-0.00154 & -0.00384 & 0.00248 & $0.01326 *$ & 0.00196 & 0.00678 \\
{$[0.00316]$} & {$[0.00992]$} & {$[0.00209]$} & {$[0.00654]$} & {$[0.00000]$} & {$[0.00521]$} \\
2323 & 553 & 10608 & 1551 & 15046 & 2144 \\
\hline
\end{tabular}

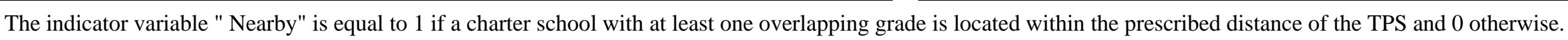
Robust standard errors in brackets are adjusted for clustering at the school level.

Note: Log of new hires is $\ln$ (total new hires +1 ).

** $\mathrm{p}<0.01, * \mathrm{p}<0.05,+\mathrm{p}<0.1$ 
Table 7: Effect of Charter Entry Within 10 Miles on Predicted Teacher Value Added (all teachers) and Estimated Value-Added (teachers who were in the data before 1998).

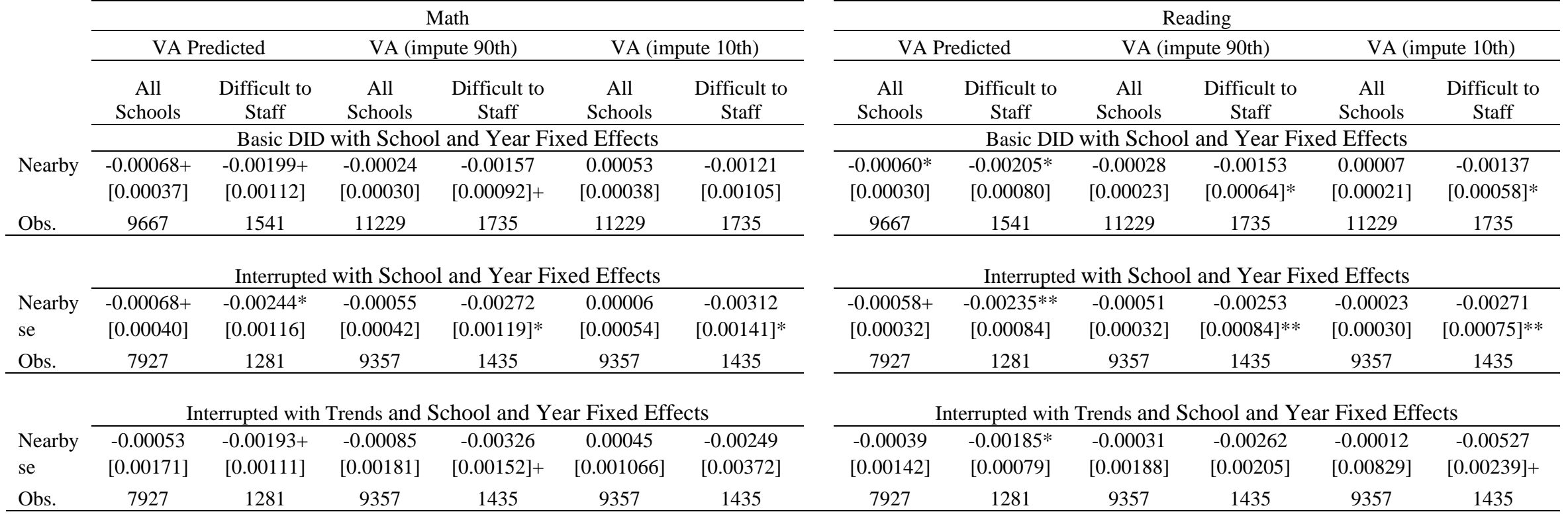

The indicator variable " Nearby" is equal to 1 if a charter school with at least one overlapping grade is located within the prescribed distance of the TPS and 0 otherwise.

Robust standard errors in brackets.

** $\mathrm{p}<0.01, * \mathrm{p}<0.05,+\mathrm{p}<0.1$ 
Table 8: Effects of Charter Entry Over Time.

\begin{tabular}{|c|c|c|c|c|c|c|c|c|}
\hline \multicolumn{9}{|c|}{ Dynamic Effects of Charter entry within 10 miles } \\
\hline & \multicolumn{2}{|c|}{ School and Year FX } & \multicolumn{2}{|c|}{$\begin{array}{l}\text { School and Year FX with } \\
\text { trends Interrupted }\end{array}$} & \multicolumn{2}{|c|}{ School and Year FX } & \multicolumn{2}{|c|}{$\begin{array}{l}\text { School and Year FX } \\
\text { with trends Interrupted }\end{array}$} \\
\hline & $\begin{array}{c}\text { All } \\
\text { Schools } \\
\end{array}$ & $\begin{array}{l}\text { Difficult to } \\
\text { Staff }\end{array}$ & $\begin{array}{c}\text { All } \\
\text { Schools }\end{array}$ & $\begin{array}{l}\text { Difficult to } \\
\text { Staff }\end{array}$ & $\begin{array}{c}\text { All } \\
\text { Schools } \\
\end{array}$ & $\begin{array}{l}\text { Difficult } \\
\text { to Staff }\end{array}$ & $\begin{array}{c}\text { All } \\
\text { Schools }\end{array}$ & $\begin{array}{c}\text { Difficult } \\
\text { to Staff }\end{array}$ \\
\hline & \multicolumn{4}{|c|}{ Exit } & \multicolumn{4}{|c|}{ Move to Charter } \\
\hline Nearby & $\begin{array}{l}-0.00588 \\
{[0.00401]}\end{array}$ & $\begin{array}{c}0.00064 \\
{[0.01315]}\end{array}$ & $\begin{array}{l}-0.00975 \\
{[0.00569]}\end{array}$ & $\begin{array}{c}-0.01424 \\
{[0.01426]}\end{array}$ & $\begin{array}{l}0.00172^{* *} \\
{[0.00055]}\end{array}$ & $\begin{array}{c}0.00191 \\
{[0.00119]}\end{array}$ & $\begin{array}{l}0.00154^{* *} \\
{[0.00058]}\end{array}$ & $\begin{array}{c}0.00150 \\
{[0.00138]}\end{array}$ \\
\hline Lag & $\begin{array}{l}-0.00792+ \\
{[0.00447]}\end{array}$ & $\begin{array}{c}-0.01435 \\
{[0.01458]}\end{array}$ & $\begin{array}{l}-0.01461 \\
{[0.01012]}\end{array}$ & $\begin{array}{c}0.00301 \\
{[0.03417]}\end{array}$ & $\begin{array}{l}-0.00076 \\
{[0.00057]}\end{array}$ & $\begin{array}{c}0.00066 \\
{[0.00143]}\end{array}$ & $\begin{array}{c}-0.00104 \\
{[0.00060]}\end{array}$ & $\begin{array}{c}-0.00012 \\
{[0.00145]}\end{array}$ \\
\hline Second & $\begin{array}{l}-0.00456 \\
{[0.00385]}\end{array}$ & $\begin{array}{l}-0.02436^{*} \\
{[0.01221]}\end{array}$ & $\begin{array}{l}-0.00298 \\
{[0.00899]}\end{array}$ & $\begin{array}{l}-0.01325 \\
{[0.02878]}\end{array}$ & $\begin{array}{l}-0.00054+ \\
{[0.00028]}\end{array}$ & $\begin{array}{l}-0.00164 \\
{[0.00116]}\end{array}$ & $\begin{array}{l}-0.00105^{*} \\
{[0.00046]}\end{array}$ & $\begin{array}{l}-0.00213^{*} \\
{[0.00098]}\end{array}$ \\
\hline $\begin{array}{l}\text { Observations } \\
\text { Effect after } 3 \\
\text { se. }\end{array}$ & $\begin{array}{c}13860 \\
-0.0184 * * \\
{[0.00446]}\end{array}$ & $\begin{array}{c}2021 \\
-0.0381 * \\
{[0.0160]}\end{array}$ & $\begin{array}{c}11604 \\
-0.02734^{* *} \\
{[0.00622]}\end{array}$ & $\begin{array}{c}1681 \\
-0.02448 \\
{[0.01962]}\end{array}$ & $\begin{array}{c}13860 \\
0.00042 \\
{[0.00028]}\end{array}$ & $\begin{array}{c}2021 \\
0.00093 \\
{[0.0011]}\end{array}$ & $\begin{array}{c}11604 \\
-0.00055 \\
{[0.00622]}\end{array}$ & $\begin{array}{c}1681 \\
-0.00075 \\
{[0.00143]}\end{array}$ \\
\hline & \multicolumn{4}{|c|}{ Log of new hires } & \multicolumn{4}{|c|}{ Log of residual salary } \\
\hline Nearby & $\begin{array}{l}-0.05306^{*} \\
{[0.02136]}\end{array}$ & $\begin{array}{l}-0.10640+ \\
{[0.05834]}\end{array}$ & $\begin{array}{c}-0.08482 * * \\
{[0.02360]}\end{array}$ & $\begin{array}{c}-0.14345^{* *} \\
{[0.05969]}\end{array}$ & $\begin{array}{c}0.00206 \\
{[0.00145]}\end{array}$ & $\begin{array}{l}0.00981+ \\
{[0.00537]}\end{array}$ & $\begin{array}{c}0.00137 \\
{[0.00203]}\end{array}$ & $\begin{array}{c}0.01104 \\
{[0.00672]}\end{array}$ \\
\hline Lag & $\begin{array}{l}-0.00936 \\
{[0.02165]}\end{array}$ & $\begin{array}{c}0.02039 \\
{[0.06336]}\end{array}$ & $\begin{array}{c}-0.0205 \\
{[0.04396]}\end{array}$ & $\begin{array}{c}0.00853 \\
{[0.10462]}\end{array}$ & $\begin{array}{c}0.00219 \\
{[0.00150]}\end{array}$ & $\begin{array}{c}0.0025 \\
{[0.00505]}\end{array}$ & $\begin{array}{c}0.00566 \\
{[0.00344]}\end{array}$ & $\begin{array}{c}0.00403 \\
{[0.01397]}\end{array}$ \\
\hline Second & $\begin{array}{c}-0.02227 \\
{[0.02147]}\end{array}$ & $\begin{array}{c}-0.10658+ \\
{[0.05712]}\end{array}$ & $\begin{array}{c}-0.00855 \\
{[0.04337]}\end{array}$ & $\begin{array}{c}-0.03436 \\
{[0.09916]}\end{array}$ & $\begin{array}{c}-0.00098 \\
{[0.00145]}\end{array}$ & $\begin{array}{c}0.00874 * \\
{[0.00404]}\end{array}$ & $\begin{array}{c}-0.00354 \\
{[0.00446]}\end{array}$ & $\begin{array}{c}0.01884 \\
{[0.01195]}\end{array}$ \\
\hline $\begin{array}{l}\text { Observations } \\
\text { Effect after } 3 \\
\text { se. }\end{array}$ & $\begin{array}{c}12601 \\
-0.0847^{* *} \\
{[0.0274]} \\
\end{array}$ & $\begin{array}{c}1855 \\
-0.193 * * \\
{[0.0781]} \\
\end{array}$ & $\begin{array}{c}10481 \\
-0.11387^{* *} \\
{[0.0355]} \\
\end{array}$ & $\begin{array}{c}1551 \\
-0.16928^{* *} \\
{[0.0623]} \\
\end{array}$ & $\begin{array}{c}12601 \\
0.00327+ \\
{[0.00188]}\end{array}$ & $\begin{array}{c}1855 \\
0.02105^{* *} \\
{[0.00593]} \\
\end{array}$ & $\begin{array}{c}10481 \\
0.00349+ \\
{[0.00211]}\end{array}$ & $\begin{array}{c}1551 \\
0.03391^{* *} \\
{[0.00954]}\end{array}$ \\
\hline & \multicolumn{4}{|c|}{ Predicted Value Added Reading } & \multicolumn{4}{|c|}{ Predicted Value Added Math } \\
\hline Nearby & $\begin{array}{c}-0.00080^{* *} \\
{[0.00030]}\end{array}$ & $\begin{array}{c}-0.00206 * * \\
{[0.00079]}\end{array}$ & $\begin{array}{c}-0.0005 \\
{[0.00040]}\end{array}$ & $\begin{array}{c}-0.00203^{* *} \\
{[0.00074]}\end{array}$ & $\begin{array}{c}-0.00100 * * \\
{[0.00037]}\end{array}$ & $\begin{array}{c}-0.00191 \\
{[0.00116]}\end{array}$ & $\begin{array}{c}-0.00069 \\
{[0.00052]}\end{array}$ & $\begin{array}{c}-0.00231 * \\
{[0.00104]}\end{array}$ \\
\hline Lag & $\begin{array}{c}0.00026 \\
{[0.00027]}\end{array}$ & $\begin{array}{c}-0.00015 \\
{[0.00097]}\end{array}$ & $\begin{array}{c}0.00084 \\
{[0.00065]}\end{array}$ & $\begin{array}{c}0.00104 \\
{[0.00211]}\end{array}$ & $\begin{array}{c}0.00046 \\
{[0.00039]}\end{array}$ & $\begin{array}{c}-0.00049 \\
{[0.00153]}\end{array}$ & $\begin{array}{c}0.0014 \\
{[0.00100]}\end{array}$ & $\begin{array}{c}0.00246 \\
{[0.00283]}\end{array}$ \\
\hline Second & $\begin{array}{c}-0.00005 \\
{[0.00031]}\end{array}$ & $\begin{array}{c}0.00057 \\
{[0.00093]}\end{array}$ & $\begin{array}{c}-0.00022 \\
{[0.00052]}\end{array}$ & $\begin{array}{c}0.00006 \\
{[0.00210]}\end{array}$ & $\begin{array}{c}-0.00007 \\
{[0.00043]}\end{array}$ & $\begin{array}{c}0.00119 \\
{[0.00133]}\end{array}$ & $\begin{array}{c}-0.00054 \\
{[0.00106]}\end{array}$ & $\begin{array}{c}-0.00024 \\
{[0.00281]}\end{array}$ \\
\hline $\begin{array}{l}\text { Observations } \\
\text { Effect after } 3 \\
\text { se. }\end{array}$ & $\begin{array}{c}9403 \\
-0.000593 \\
{[0.00045]}\end{array}$ & $\begin{array}{c}1541 \\
-0.00163 \\
{[0.00124]}\end{array}$ & $\begin{array}{c}7845 \\
0.00012 \\
{[0.00069]}\end{array}$ & $\begin{array}{c}1281 \\
-0.00093 \\
{[0.00080]}\end{array}$ & $\begin{array}{c}9403 \\
-0.00061 \\
{[0.00059]}\end{array}$ & $\begin{array}{c}1541 \\
-0.00120 \\
{[0.00164]}\end{array}$ & $\begin{array}{c}7845 \\
0.00017 \\
{[0.0068]}\end{array}$ & $\begin{array}{c}1281 \\
-0.00009 \\
{[0.00121]}\end{array}$ \\
\hline
\end{tabular}

The indicator variable " Nearby " is equal to 1 if a charter school with at least one overlapping grade is located within the prescribed distance of the TPS and 0 otherwise.

Robust standard errors in brackets.

${ }^{* *} \mathrm{p}<0.01,{ }^{*} \mathrm{p}<0.05,+\mathrm{p}<0.1$ 
Effect of Charter Entry Within Teacher Supply Area: By Labor Demand Regime (Only A Supply Response, No Demand Response)

Charter School Labor Market

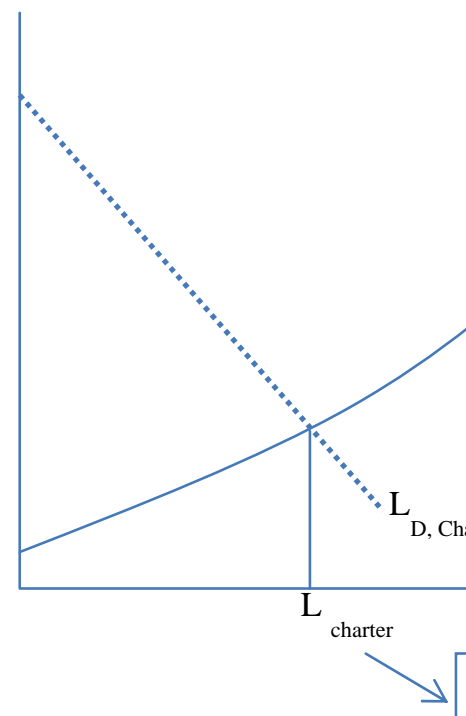

Public School Labor Market: With and Without Flexible Wages

Figure 1: Charter Entry and Teacher at Traditional Public Schools with a Labor Supply Response.

Effect of Charter Entry Within Teacher Supply Area: By Labor Demand Regime (Both A Supply and A Demand Response)

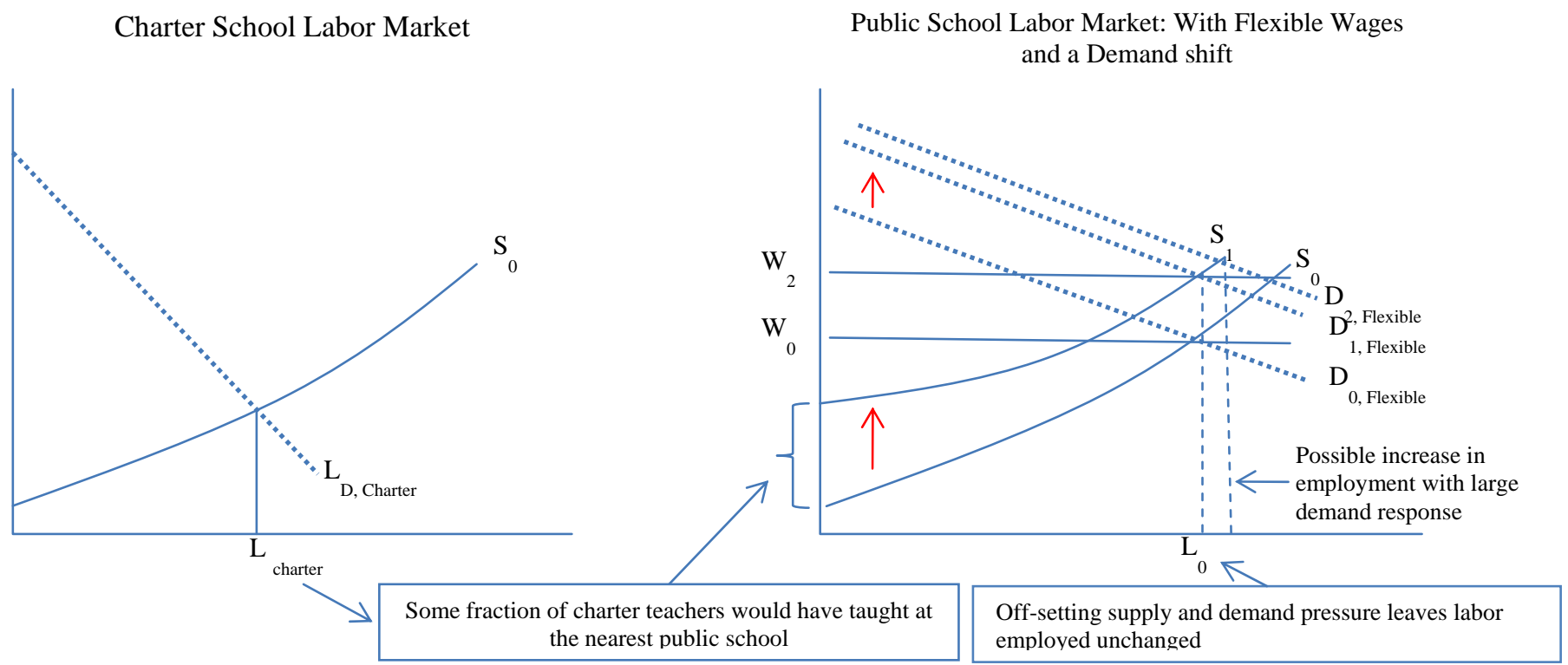

Figure 2: Charter Entry and Teacher at Traditional Public Schools with Both a Labor Supply and a Labor Demand Response. 

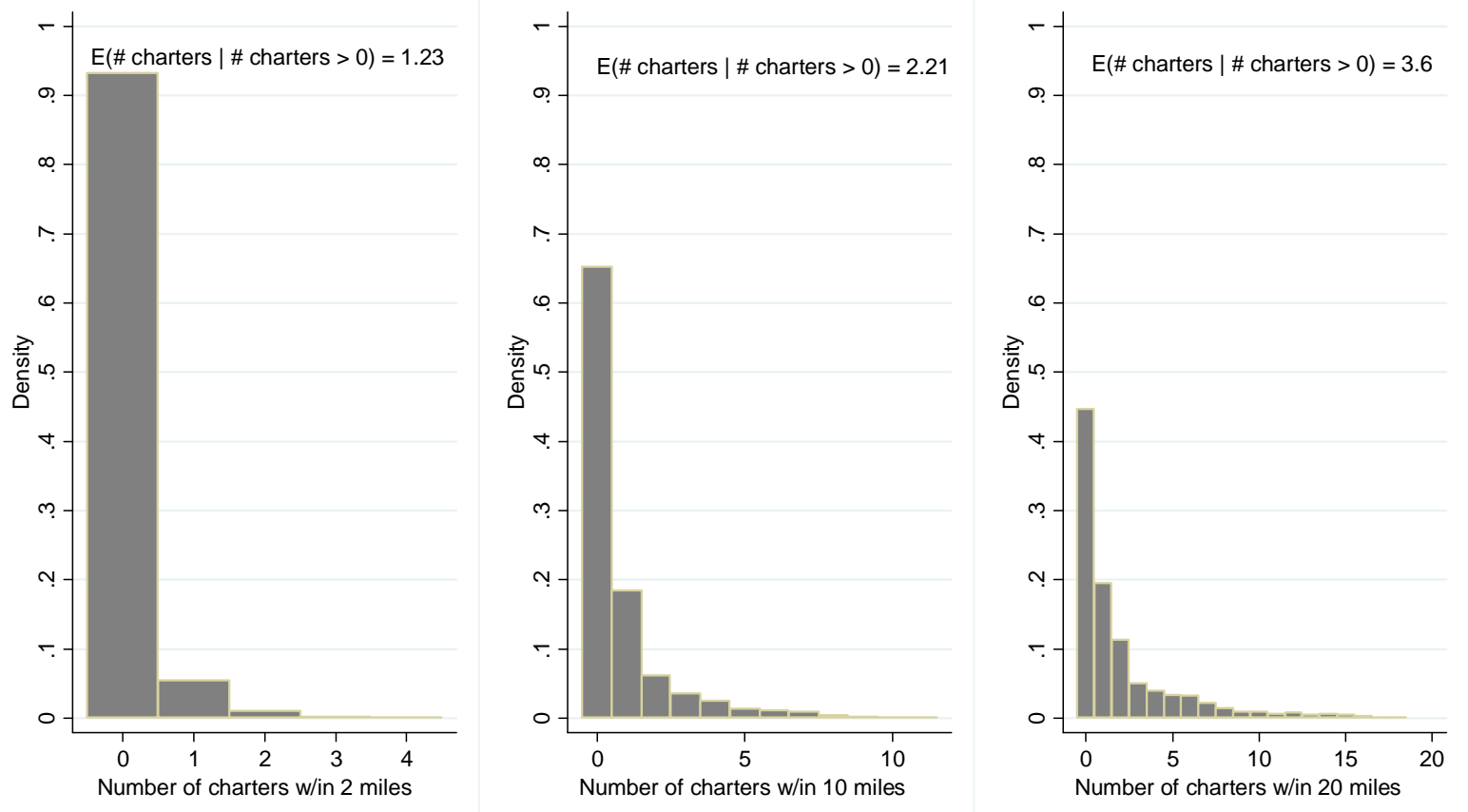

Figure 3: Number of Nearby Charter Schools Conditional on Charter Entry. 

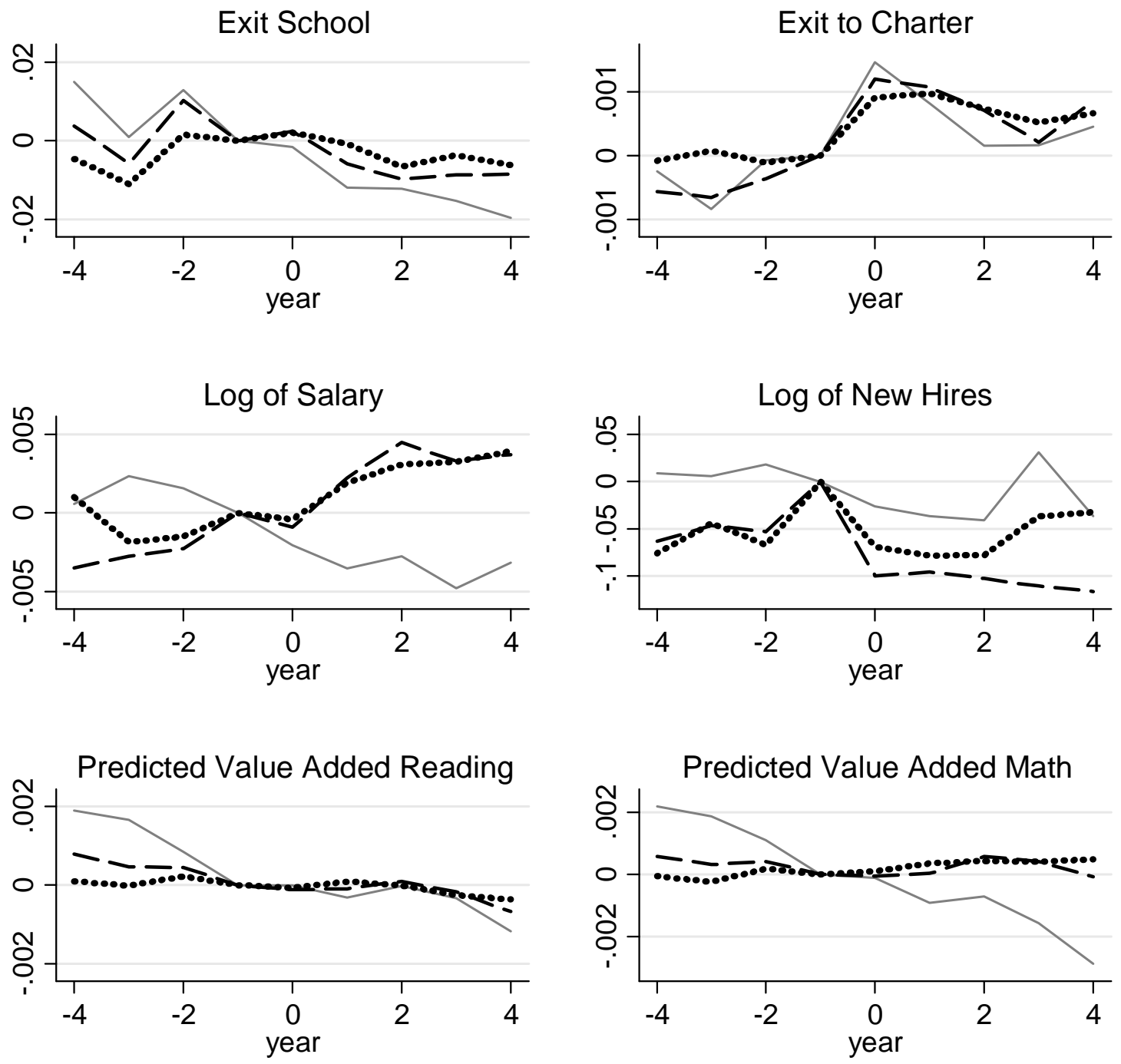

(grey) - 2 Miles - - - 10 Miles •... 20 Miles

Figure 4: Effect of Charter Entry on Staffing and Teacher Quality. 
Effect of Entry Within 10 Miles on Teacher Experience: Difficult to Staff Schools

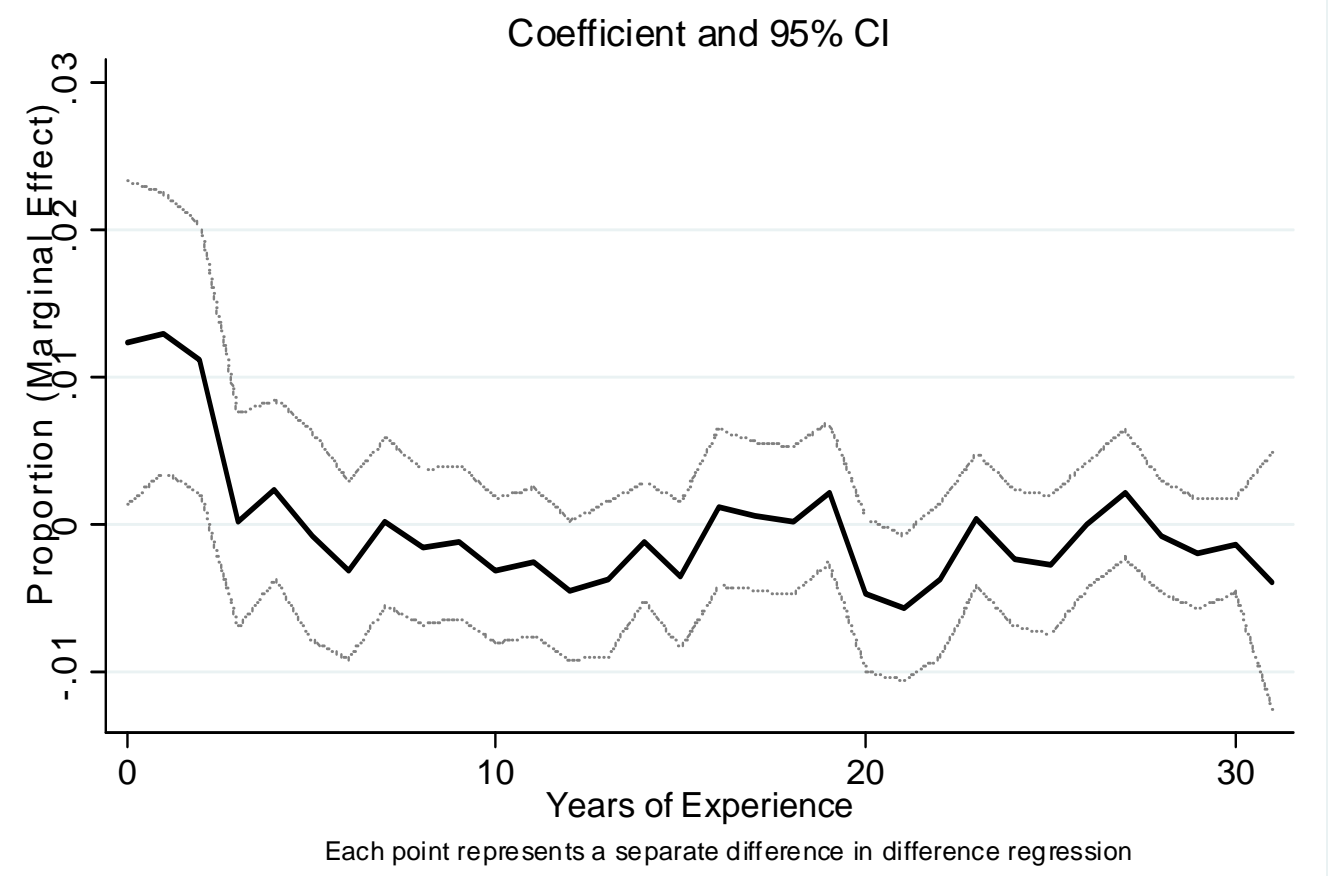

Figure 5: Effect of charter entry within 10 miles on the distribution of teacher experience at difficult to staff schools.
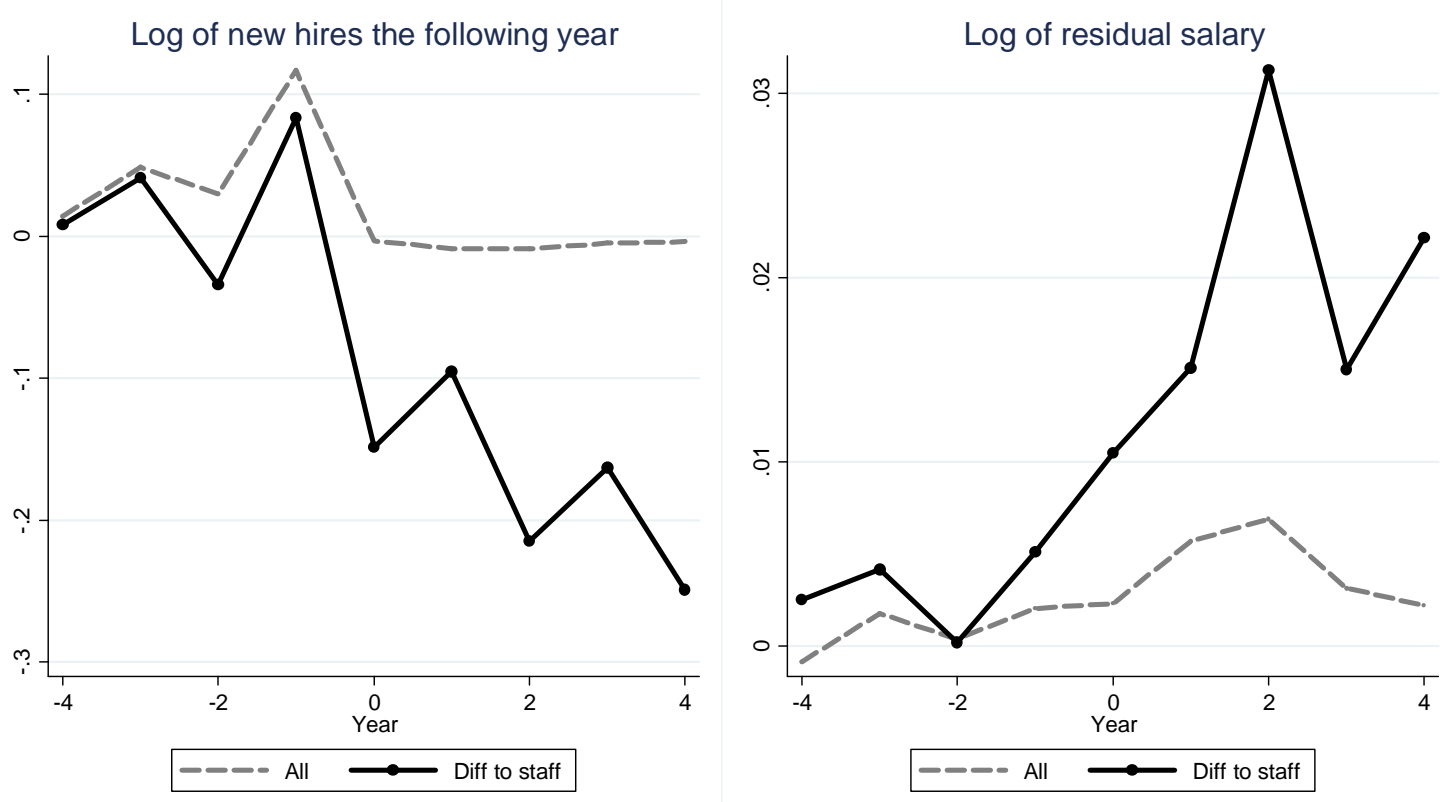

Figure 6: Effects of charter entry (within 10 miles) on salary and new hires at difficult to staff schools. 


\section{Appendix:}

Appendix Table 1: Selected Teacher Survey Results

\begin{tabular}{lrr} 
& Public & Charter \\
\hline Teachers have reasonable student loads. & 3.186 & 4.373 \\
& $(1.50)$ & $(1.51)$ \\
Leadership tries to address concerns about time. & 3.692 & 4.012 \\
& $(1.49)$ & $(1.50)$ \\
Teachers have a range of support personnel. & 3.689 & 3.245 \\
& $(1.40)$ & $(1.55)$ \\
Principal is a strong, supportive leader. & 4.359 & 4.415 \\
& $(1.59)$ & $(1.58)$ \\
Administrators give priority to supporting teachers. & 3.926 & 4.071 \\
& $(1.42)$ & $(1.45)$ \\
New teachers have effective mentors. & 4.261 & 3.504 \\
& $(1.40)$ & $(1.68)$ \\
Teachers are centrally involved in decision-making. & 3.591 & 4.098 \\
& $(1.47)$ & $(1.55)$ \\
Teachers are recognized as educational experts. & 3.918 & 4.555 \\
& $(1.50)$ & $(1.42)$ \\
There is an atmosphere of mutual respect at school. & 3.869 & 4.289 \\
& $(1.46)$ & $(1.50)$ \\
Leadership tries to provide quality professional development. & 4.214 & 4.508 \\
& $(1.38)$ & $(1.43)$ \\
\hline Observations & 31822 & 245 \\
\hline
\end{tabular}

This presents the means of survey data for charter teachers and non-charter school teachers about their impressions of their school work environment from the Working Conditions Survey administered by the North Carolina Professional Teaching Standards Commission in 2002. A score of 0 means highly disagree while a score of 5 means highly agree. Since charter school teachers may differ from noncharter teachers in how they perceive their workplace environments, differences across these groups are suggestive. 
Appendix Note 1: Empirical Bayes Estimates: While teacher effects that come directly from [1] should yield consistent estimates of teacher value added, a more efficient estimate is the Empirical Bayes (EB) estimate that shrinks noisy value added estimates towards the mean of the value added distribution (in this case zero). Where $u_{j}$ is random estimation error $\hat{\tau}_{j}=\tau_{j}+u_{j}$, and $\tau_{j} \sim N(0, \operatorname{Var}(\tau))$, so that the total variance of the estimated effects is $\operatorname{Var}\left(\hat{\tau}_{j}\right)=\operatorname{Var}(\tau)+\operatorname{Var}\left(u_{j}\right)$. With estimation error $E\left[\tau_{j} \mid \hat{\tau}_{j}\right]=\left(\sigma_{\tau}^{2} /\left(\sigma_{\tau}^{2}+\sigma_{u_{j}}^{2}\right)\right) \cdot \hat{\tau}_{j}$. The empirical analog of this conditional expectation is an EB estimate. I follow Kane and Staiger (2008) to compute the EB estimates. This approach accounts for the fact that (1) teachers with larger classes will tend to have more precise estimates and (2) there are classroom level disturbances so that teachers with multiple classrooms will have more precise value added estimates. To simplify notation, I subsume all observed covariates into a single variable $X_{j t}$ and drop the grade subscript $g$ to re-write equation [3] as [A1] below.

$$
A_{i j t}-A_{i j t-1}=\eta X_{j t}+\tau_{j}+v_{j t}+\varepsilon_{i j t}
$$

In [A1], the total error term is $z_{i j t}=\tau_{j}+v_{j t}+\varepsilon_{i j t}$. Since the student error component is equal to zero in expectation, the mean residual for classroom $j t, c_{j t}=\tau_{j}+v_{j t}$, contains the teacher effect and the idiosyncratic classroom error. Since classroom errors are random, I use the covariance between mean residuals of adjacent classrooms for the same teacher $\operatorname{cov}\left(c_{j t}, c_{j t-1}\right)=\hat{\sigma}_{\tau}^{2}$ as an estimate of the variance of true teacher quality. I use the variance of the classroom demeaned residuals as an estimate of $\hat{\sigma}_{\varepsilon}^{2}$. Since the variance of the residuals is equal to the sum of the variances of the true teacher effect, the classroom effect, and the student error, I compute the classroom error variance $\sigma_{v}^{2}$ by subtracting $\sigma_{\varepsilon}^{2}$ and $\sigma_{\tau}^{2}$ from the total variance of the residuals.

For each teacher, I compute a weighted average of their mean classroom residuals, where classrooms with more students are more heavily weighted. Specifically I compute

$$
\bar{\tau}_{j}=\sum_{t=1}^{T_{j}} c_{j t} \cdot \frac{1 /\left[\sigma_{v}^{2}+\left(\sigma_{\varepsilon}^{2} / N_{j t}\right)\right]}{\sum_{t=1}^{T_{j}} 1 /\left[\sigma_{v}^{2}+\left(\sigma_{\varepsilon}^{2} / N_{j t}\right)\right]}
$$

Where $N_{j t}$ is the number of students in classroom $j$ t, and $T_{j}$ is the total number of classrooms for teacher $j$. To obtain an EB estimate for each teacher, I multiply the weighted average of classroom residuals $\bar{\tau}_{j}$ by an estimate of its reliability. Specifically, I compute

$$
\hat{\tau}_{j}^{E B}=\bar{\tau}_{j} \cdot \hat{\sigma}_{\tau}^{2} /\left(\hat{\sigma}_{\tau}^{2}+\sigma_{u_{j}}^{2}\right)
$$

where $\sigma_{u_{j}}^{2}=\left(\sum_{t=1}^{T_{j}}\left(1 /\left[\sigma_{v}^{2}+\left(\sigma_{\varepsilon}^{2} / N_{j t}\right)\right]\right)^{-1}\right.$ is the estimation variance of the raw value added estimate. The shrinkage factor $\hat{\sigma}_{\tau}^{2} /\left(\hat{\sigma}_{\tau}^{2}+\sigma_{u_{j}}^{2}\right)$ is the ratio of signal variance to total variance and is a measure of how reliable an estimate $\bar{\tau}_{j}$ is for $\tau_{j}$. 